\title{
Deep-water Actiniaria from East Pacific hydrothermal vents and cold seeps
}

\author{
N.P. Sanamyan, K.E. Sanamyan \\ Kamchatka Branch of the Pacific Institute of Geography FEB RAS, Partizanskaya 6, Petropavlovsk- \\ Kamchatsky 683000, Russia. \\ e-mail: actiniaria@sanamyan.com
}

\begin{abstract}
Four species of sea anemones from East Pacific hydrothermal vents and one species from cold seeps are discussed. A species from cold seeps, Seepactis galkini gen. nov., sp. nov, possesses acontia and belongs to Kadosactiidae. Previously the specimens of this species were preliminarily referred to the ultraabyssal actinostolid Hadalanthus knudseni. Cyananthea hydrothermala, an obligate hydrothermal species and genus known previously only from an incomplete damaged specimen is redescribed and tentatively assigned to the Actinoscyphiidae. Cyananthea is closely related to several monotypic genera described recently from hydrothermal vents, especially to Pacmanactis and Marianactis which were assigned to the Actinostolidae by their authors. In our opinion these genera should be removed from the Actinostolidae and placed in the same family as Cyananthea. Three other recorded species belong to the Hormathiidae: Phelliactis hydrothermala sp.n., Phelliactis callicyclus and Paraphelliactis pabista.
\end{abstract}

KEY WORDS: Actiniaria, Anthozoa, Cnidaria, hydrothermal vents, cold seeps, deep-water fauna.

\section{Глубоководные Actiniaria из восточно-тихоокеанских гидротермальных источников и холодных сипов}

\author{
Н.П. Санамян, К.Э. Санамян
}

Камчатский филиал Тихоокеанского института географии ДВО РАН, Партизанская 6, Петропавловск-Камчатский 683000, Россия.

e-mail: actiniaria@sanamyan.com

РЕЗЮМЕ: Обсуждаются четыре вида актиний с восточно-тихоокеанских гидротерм и один вид с холодных сипов. Вид из холодных сипов, Seepactis galkini gen. nov., sp. nov, имеет аконтии и относится к семейству Kadosactiidae. Ранее экземпляры этого вида предварительно считали идентичными ультраабиссальному представителю семейства Actinostolidae Hadalanthus knudseni. Cyananthea hydrothermala, облигатный гидротермальный вид и род, известный ранее только по одному поврежденному экземпляру, переописан нами и предварительно отнесен к семейству Actinoscyphiidae. Cyananthea близко родственна нескольким монотипическим родам, описанным в последнее время с гидротерм, особенно родам Pacmanactis и Marianactis, которые описавшими их авторами были отнесены к семейству Actinostolidae. По нашему мнению, эти рода следует удалить из актиностолид и поместить в одно семейство с 
Cyananthea. Три других вида относятся к семейству Hormathiidae: Phelliactis hydrothermala sp.n., Phelliactis callicyclus и Paraphelliactis pabista.

КЛЮЧЕВЫЕ СЛОВА: Actiniaria, Anthozoa, Cnidaria, гидротермальные источники, холодные сипы, глубоководная фауна.

\section{Introduction}

During the cruise 22 of RV "Keldish" in 1990, two research submersibles MIR-1 and MIR-2 discovered a cold seep site in the Monterey Canyon on the depth about $3040 \mathrm{~m}$. This small, about $70 \mathrm{~m}^{2}$, site was inhabited by large bivalves related to Calyptogena spp. known from many hydrothermal sites (Moskalev, 2002). These bivalves were subsequently described as Ectenagena extenta Krylova et Moskalev, 1996, and in the present paper we describe the sea anemone Seepactis galkini gen. nov., sp.n. attached to the anterior end of some specimens of E. extenta. This anemone possesses acontia and belongs to the Kadosactiidae, a family never reported before from cold seeps or hydrothermal vents.

During the same cruise and during cruise 49 of RV "Keldish" in 2003 the submersibles MIR1 and MIR-2 explored several hydrothermal sites in the Eastern Pacific where, among other species, several sea anemones were collected. The present paper describes sea anemones collected in three hydrothermal sites: Guaymas Basin, East Pacific Rise (EPR) $21^{\circ} \mathrm{N}$ and EPR $9^{\circ} \mathrm{N}$. These hydrothermal sites belong to eastsoutheast regional type characterized by the presence of vestimentiferas Riftia pachyptila, polychaetes Alvinella pompejana, and, in the cold vent zone, bivalves of the families Vesicomyidae and Mytilidae. Inside this region the fauna of the Guaymas Basin differs significantly from the other sites and belongs to a different biogeographical province (Galkin, 2002). Guaymas Basin is characterized by extremely thick (more than $500 \mathrm{~m}$ ) layer of sediments and very high hydrothermal buildings. Many small sea anemones were reported in the warm vent zone (shimmering water zone) on the terraces of the hydrothermal buildings (Galkin, 2002), but unfortunately these anemones are not present in the examined material. The present material from Guaymas hydrothermal site contains several specimens of the large sea anemones Paraphelliactis pabista Dunn, 1982, one of which was attached to a Calyptogena shell, and a specimen of Phelliactis callicyclus RiemannZürneck, 1973. The material collected on EPR $21^{\circ} \mathrm{N}$ includes Phelliactis hydrothermala sp.n., a large species collected in the zone of the black and white smokers, Cyananthea hydrothermala Doumenc et Van-Praët, 1988, and numerous zooids of Isozoanthus sp. (order Zoantharia, Anthozoa, Cnidaria). Only C. hydrothermala is present in the material from EPR $9^{\circ} \mathrm{N}$.

Cnidae terminology follows England (1991) although we do not distinguish between amastigophores and p-mastigophores. Two types of spirocysts with the following definition are distinguished (modified from Fautin and Barber, 1999: 627):

Robust spirocysts (often called also 'Hormathiid' spirocysts): spirocysts with tubules wound in an untidy fashion and lacked space between the tubule and the capsule's posterior end. They are, in average, wider, but not necessary longer that the spirocysts of the other type.

Gracile spirocysts (the term used by Daly et al, 2004): spirocysts with neatly wound tubules and with the space between the tubule and the posterior end of the capsule. They are, in average, narrower than the robust spirocysts.

The specimens are deposited in Zoological Museum of Moscow State University (ZMMU) and Institute of Oceanology RAS, Moscow (IORAS).

\section{Station list}

Fig. 1.

Monterey Canyon, cold seeps, $R V$ "Keldish", cruise 22:

St. $2350,3028-3045 \mathrm{~m}, 36^{\circ} 36.6^{\prime} \mathrm{N}, 122^{\circ} 30.4^{\prime}$ W-36 35.2' N, 122 31.4' W, 21-22 September 1990. 


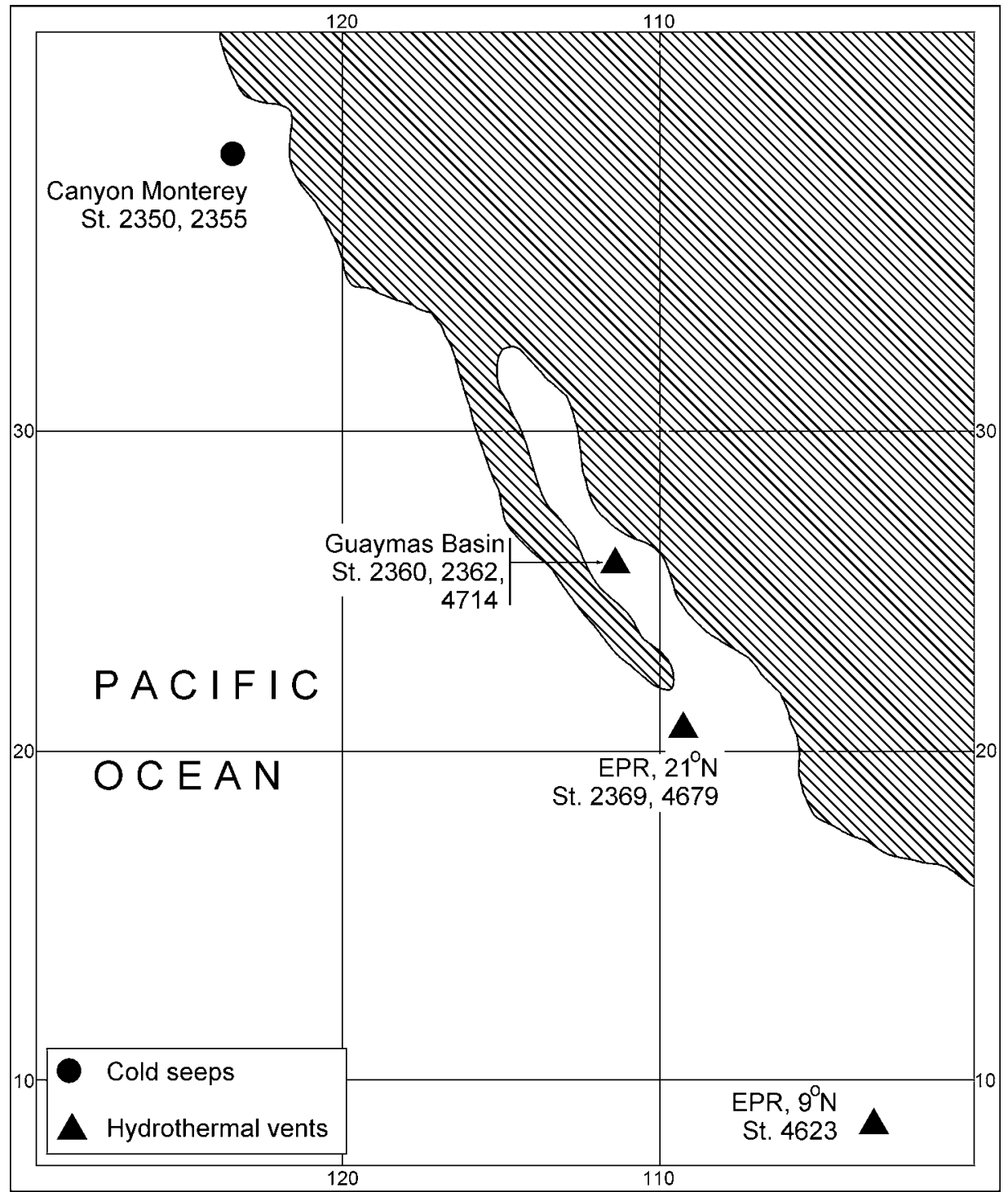

Fig. 1. Map showing locality of cold seep and hydrothermal vents and stations where the present material was collected.

Рис.1. Местонахождения холодных сипов и гидротермальных источников, где был собран настоящий материал.

St. $2355,3040 \mathrm{~m}, 36^{\circ} 35.3^{\prime} \mathrm{N}, 122^{\circ} 30.5^{\prime} \mathrm{W}, 24$ September 1990.

Guaymas Basin, hydrothermal vents, $R V$ "Keldish", cruise 22 and 49 .

St. $2360,2033-2034 \mathrm{~m}, 26^{\circ} 59.53^{\prime} \mathrm{N}, 111^{\circ} 24.81^{\prime}$

$\mathrm{W}-27^{\circ} 01.03^{\prime} \mathrm{N}, 111^{\circ} 24.68^{\prime} \mathrm{W}, 09-10$ October 1990 . St. $2362,1950-2050 \mathrm{~m}, 27^{\circ} 00^{\prime} \mathrm{N}, 111^{\circ} 24^{\prime} \mathrm{W}, 11$ October 1990.

St. $4714,2000 \mathrm{~m}, 27^{\circ} 00^{\prime} \mathrm{N}, 111^{\circ} 24^{\prime}$ W. Sample 5 . At the foot of the hydrothermal building.
Eastern Pacific Rise (EPR), $21^{\circ} \mathrm{N}$, hydrothermal vents, $R V$ "Keldish", cruise 22

St. $2369,2640 \mathrm{~m}, 20^{\circ} 50.40^{\prime} \mathrm{N}, 109^{\circ} 05.73^{\prime} \mathrm{W}$, 18-19 October 1990.

St. 4679,2596 and $2602 \mathrm{~m}, 20^{\circ} 50^{\prime} \mathrm{N}, 109^{\circ} 05^{\prime}$ W, 9 October 2003

Eastern Pacific Rise (EPR), $9^{\circ} \mathrm{N}$, Musselbed, hydrothermal vents, $R V$ "Keldish", cruise 49:

St. $4623,2524 \mathrm{~m}, 9^{\circ} 50.53^{\prime} \mathrm{N}, 104^{\circ} 17.52^{\prime} \mathrm{W}, 5$ September 2003. 


\section{Description of species}

\section{Family Kadosactiidae}

\section{Seepactis Sanamyan et Sanamyan gen.n.}

Type species: Seepactis galkini Sanamyan et Sanamyan sp.n.

Definition. Kadosactiidae with broad adherent pedal disc. Column divided in scapus and scapulus. Scapus with numerous papillae covered with cuticle. No cinclides. Sphincter mesogloeal, strong. Longitudinal muscles of the tentacles and radial muscles of the oral disc ectodermal to meso-ectodermal. Mesenteries more numerous distally than proximally, hexamerously arranged, only first cycle perfect. Typically two siphonoglyphs and two pairs of directives. Retractors diffuse. All stronger mesenteries fertile. Acontia with basitrichs and p-mastigophores B Cnidom: robust and gracile spirocysts, heterotrichs in tentacles and column, basitrichs and medium size p-mastigophores B in all epithelia. No p-mastigophores A.

Diagnosis. Seepactis is closely related toKadosactis which differs mainly in having extraordinary large p-mastigophores (especially in acontia). Two cycles of perfect mesenteries and absence of heterotrichs in Kadosactis also may be valid features distinguishing these genera.

\section{Seepactis galkini sp.n.}

Figs 2, 3

Hadalanthus aff. knudseni: López-González et al., 2003: 299

Non Hadalanthus knudseni Carlgren, 1956: 13

Material examined. Holotype: Monterey Canyon, st. 2350, 3028-3045 m, (ZMMU Ec-105). Paratypes: Monterey Canyon, st. 2350, 3028-3045 $\mathrm{m}$, three specimens; st. 2355, $3040 \mathrm{~m}$, three specimens. Other specimens: Monterey Canyon, st. 2355, $3040 \mathrm{~m}$, two specimens.

Description. External structure. Preserved contracted specimens are hemispherical or with flattened bodies, not large, $12-32 \mathrm{~mm}$ diameter and 3$12 \mathrm{~mm}$ high (the holotype is $32 \times 10 \mathrm{~mm}$ ). Flat, wide and strongly adhesive pedal disc produces a thin sheet of yellow easily deciduous cuticle. The column is divided into scapus and scapulus. The scapus is provided with small, $0.5-1.5 \mathrm{~mm}$ diameter, flattened, hemispherical or occasionally elongated irregularly distributed mesogloeal tubercles. Each tubercle is covered with a thin cuticle often forming characteristic concentrically wrinkled caps (Fig. 2B). The cuticle is slightly darker than the ectoderm of column and stratified although the strata are few and set close to each other. Its surface is clear, without attached particles of sand or mud which are occasionally present on the scapus between the tubercles. No traces of cuticle detected between the tubercles on preserved specimens. The scapulus is smooth, without distinct scapular ridges. The tentacles are long and cylindrical, without mesogloeal swellings at the base, usually hidden by upper part of column, occasionally not completely withdrawn, the inner are longer than the outer ones. They are capable to invaginate into the body through their own bases. Such invaginated tentacles with their ectoderm turned inside are found between the mesenteries in some specimens. About 120 tentacles were counted in a 12 mm (diameter) specimen (IORAS IV-9-Act-07-004); in other specimens the number of tentacles is obscured by strong contraction and cannot be accessed without strong mutilation of the material (especially if some tentacles are invaginated into the body).

Internal structure. Pale beige ectoderm is retained on the column of almost all specimens, it is much thinner on mesogloeal tubercles than on the rest of the column. The ectoderm of the tentacles and especially of the oral disc is darker, sometimes dark brown. The mesogloea of the body is firm, up to 2 $\mathrm{mm}$ thick in the middle part of the column, about the same thickness in scapus and scapulus, but much thinner near the limbus and on the pedal disc.

The mesogloeal sphincter is strong, alveolar, with clear limits, situated close to the endoderm. It extends over the whole scapulus (where it occupies about a half of the width of the mesogloea and almost reaches the bases of tentacles), diminishes proximally and ends abruptly in the upper part of the scapus. In one specimen (ZMMU Ec-105) the sphincter was strong and well developed in a half of the body, and represented only by a weak concentration of muscle meshes near the endoderm in another half (Fig. 2D, E). In this specimen the tentacles were also unequally developed being longer and more numerous where the sphincter was well developed but strongly reduced in size and number where the sphincter was weak. Longitudinal muscles of the tentacles principally ectodermal to meso-ectodermal. Radial muscles of the oral disc ectodermal. Most specimens have two siphonoglyphs supported by directives and hexamerously arranged mesenteries. One specimen (IORAS IV-9-Act-07004) has four siphonoglyphs, four pairs of directives and irregularly arranged mesenteries. Typically only four cycles of mesenteries and occasionally several very small mesenteries of the fifth cycle are present in the middle region of the body. The mesenteries of the fifth cycle are better developed and more numerous in the most distal part of the body and the number of mesenteries is greater distally than proximally: the specimen with about 120 tentacles has about 95 mesenteries in the middle part of the body. Only the 


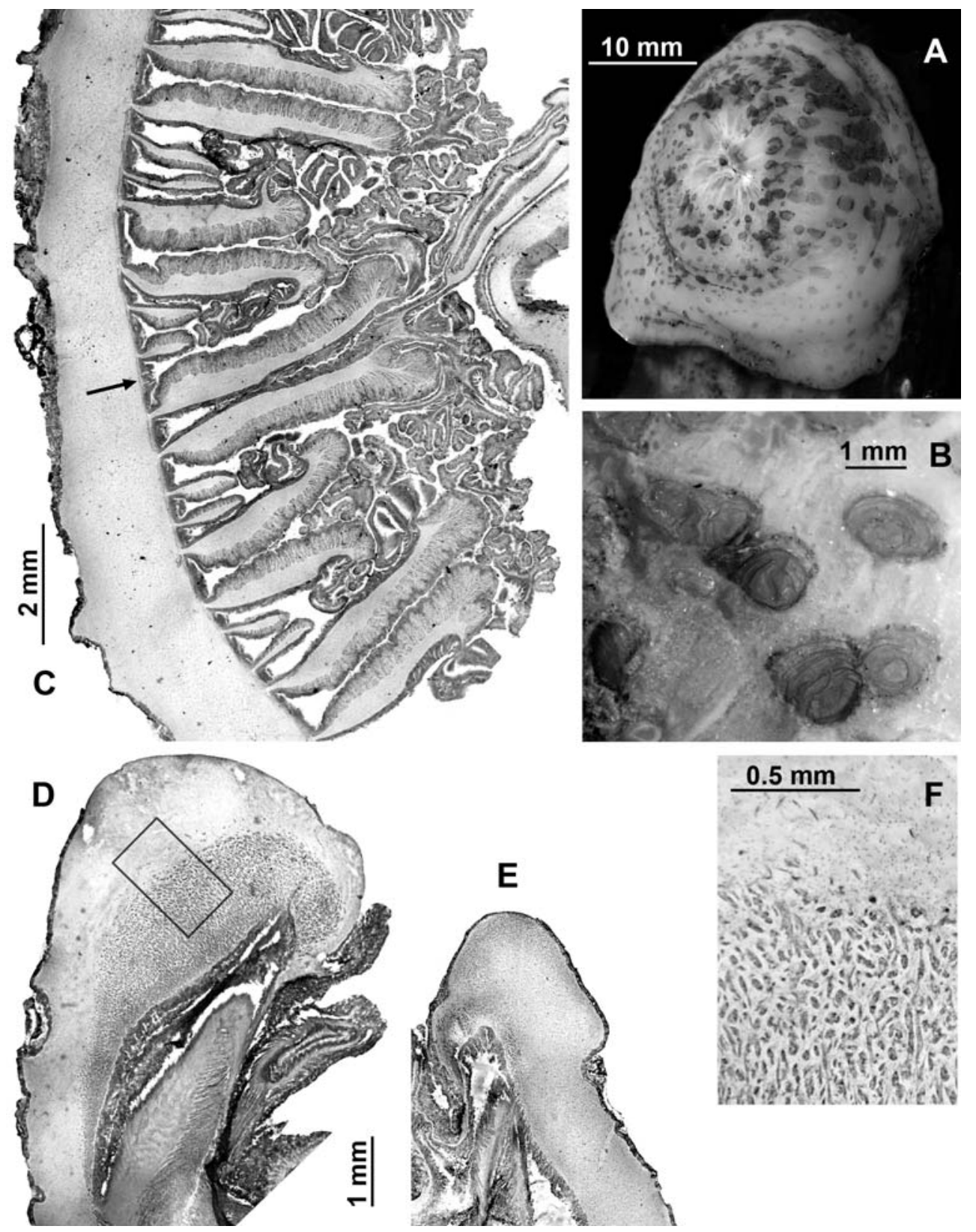

Fig. 2. Seepactis galkini sp.n.

A - external appearance; B - columnar tubercles; C - cross section of column showing mesenteries of first-fourth cycles and one very small pair of fifth cycle (arrow); D, E - cross sections of the marginal sphincter (unequally developed on opposite sides of the same specimen); F - detail of the marginal sphincter (A, B - paratype IORAS IV-9-Act-07004; C-F - holotype ZMMU Ec-105).

Рис.2. Seepactis galkini sp.n.

A - внешний вид; В - колумнарные туберкулы; C - срез колумна, показывающий мезентерии первогочетвертого циклов и одну маленькую пару пятого цикла (стрелка); D, E - срез маргинального сфинктера (неодинаково развит с двух сторон одного и того же экземпляра); F - деталь маргинального сфинктера. (А, B - паратип IORAS IV-9-Act-07-004; C-F — голотип ZMMU Ec-105). 


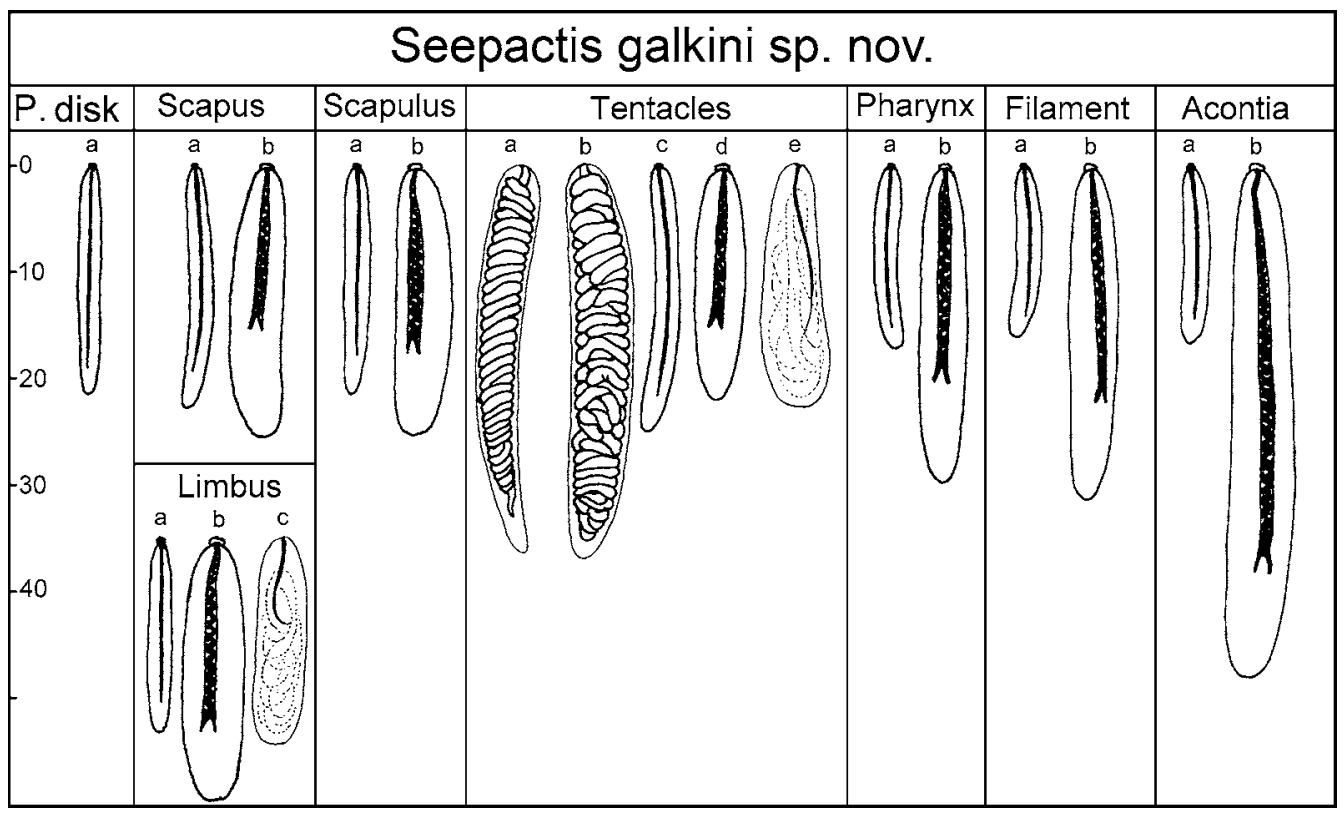

Fig. 3. Seepactis galkini sp.n., cnidom. Рис.3. Seepactis galkini sp.n., книдом.

mesenteries of the first cycle are perfect. Mesenteries of the first three cycles including the directives are fertile, those of the fourth and firth cycle are sterile and lack filaments. The retractor muscles are well developed, diffuse, long, with numerous branched lamellae arising from the thick mesogloea of the mesentery. On transverse sections the retractors almost reach the column wall. Very weak parietobasilar muscles are discernible only on some stronger mesenteries. Basilar muscles are present.

Well developed acontia were found only in one specimen (ZMMU Ec-105), they are thick (0.2-0.3 $\mathrm{mm}$ diameter) and coiled, reddish, attached to the proximal parts of the mesenteries of the first, second and third cycles. In other specimens acontia are have disintegrated, the remaining tissue and mucus containing nematocysts characteristic for acontia can be found between the mesenteries near the base.

All dissected specimens had only male gonads with the spermatic vesicles up to $1 \mathrm{~mm}$ diameter.

Size and distribution of cnidae (letters in brackets refer to Fig. 3, all measurements in microns; $\mathrm{N}$ is the proportion of examined specimens that had a particular type of cnidae):

Pedal disc: basitrichs (a) - 18-25×2-3 (common), $\mathrm{N}=5 / 5$.

Limbus: basitrichs (a) - 16-23×2-3 (common), $\mathrm{N}=4 / 4$; p-mastigophores $\mathrm{B}$ (b) - 20-26x4.5-6 (rare), $\mathrm{N}=4 / 4$; heterotrichs (c) $-17-22 \times 4.5-6$ (rare), $\mathrm{N}=4 / 4$.
Scapus: basitrichs (a) - 16-23x2-3 (common), $\mathrm{N}=5 / 5 ;$ p-mastigophores $\mathrm{B}$ (b) - 19-31x4-6 (common), $\mathrm{N}=5 / 5$.

Scapulus: basitrichs (a) - 17-23×2-3 (common), $\mathrm{N}=3 / 3$; p-mastigophores $\mathrm{B}(\mathrm{b})-18-26 \times 3.5-$ 7 (common), $\mathrm{N}=3 / 3$.

Tentacles: gracile spirocysts (a) - 18-59x2.56.5 (common), $\mathrm{N}=4 / 4$; robust spirocysts (b) - 1950x3.5-8 (numerous), $\mathrm{N}=4 / 4$; basitrichs (c) - 18$29 \times 2-3$ (common), $\mathrm{N}=4 / 4$; p-mastigophores $\mathrm{B}$ (d) - 19-38x4-6.5 (common), $\mathrm{N}=4 / 4$; heterotrichs (e) $-21-32 \times 5-7.5$ (rare), $\mathrm{N}=4 / 4$.

Actinopharynx: basitrichs (a) - 15-22x2-2.5 (common), $\mathrm{N}=3 / 4$; p-mastigophores B (b) - 2734x3.5-6 (common), $\mathrm{N}=4 / 4$.

Filaments: basitrichs (a) - 13-19x2-3 (common), $\mathrm{N}=4 / 4$; p-mastigophores $\mathrm{B}$ (b) - 21-35x46 (common), $\mathrm{N}=4 / 4$.

Acontia: basitrichs (a) - 14-20x2-2.5 (common), $\mathrm{N}=2 / 2$; p-mastigophores $\mathrm{B}$ (b) - 41-53×56.5 (common), $\mathrm{N}=2 / 2$.

Nematocysts of acontia were measured in specimens ZMMU Ec-105 and IORAS IV-9-Act-07-006 (only a small piece of acontia has been found in the latter specimen). In four other specimens p-mastigophores B characteristic for acontia (38-52x5-6.5) have been found in the mucus and disintegrated tissue between the mesenteries.

Habitat. Cold seep site, attached to shells of bivalve Ectenagena extenta. 
Etymology. The species is named after the collector, Dr. S.V. Galkin.

Remarks. The present species has acontia with basitrichs and p-mastigophores and some other features characteristic for Sagartiidae and Kadosactiidae. It cannot be assigned to any genus of Sagartiidae of which only Choriactis may bear tubercles on the column and Phellia and Sagartiogeton possess tenaculi. Choriactis has three or two cycles of perfect mesenteries and Phellia has about two times fewer tentacles than mesenteries, strong restricted retractors on the oldest cycles and almost always irregularly distributed mesenteries. Spirocysts of Choriactis and Phellia are of usual gracile (not robust) type and their cnidom is typical for Sagartiidae with p-mastigophores A in the pharynx and filaments. Sagartiogeton is a heterogeneous genus the type species of which ( $S$. robustus Carlgren, 1924) has considerably fewer tentacles than mesenteries and more than 12 pairs of perfect mesenteries. This genus currently contains more than 10 species and none is similar to $S$. galkini sp.n.

The cnidom of the present species is similar to the cnidom of Kadosactis, with p-mastigophores B in all epithelia, no p-mastigophores $\mathrm{A}$ and robust ("hormathiid") spirocysts and the species is assigned to Kadosactiidae. This family was created by Riemann-Zürneck (1991) who considered cnidom of Kadosactis rather archaic and inconsistent with its position within the family Sagartiidae. One of the most important features on which her decision was based is the absence of p-mastigophores A in Kadosactis, a feature characteristic for "early Mesomyaria", while Sagartiidae have p-mastigophores A in pharynx and filaments and are placed in the "late Mesomyaria" (Schmidt, 1974). The present species cannot be assigned to Kadosactis, which differs mainly in its extremely large p-mastigophores and also by two cycles of perfect mesenteries. The presence of the heterotrichs in S. galkini sp.n. also might constitute a valid generic difference. Although these nematocysts are not abundant and may be easily overlooked, their absence in Kadosactis appears to be real rather than apparent: heterotrichs were not recorded in K. sulcata Carlgren, 1934 and K. rosea Danielsen, 1890 (Riemann-Zürneck, 1991) and we failed to find heterotrichs in available specimens of $K$. antarctica (Carlgren, 1928). Other species assigned to Kadosactis by Carlgren (1949) (Phellia abyssicola Koren et Danielssen, 1879, P. spitzbergensis Danielsen, 1890 and Sicyopus commensalis Gravier, 1918) were removed from this genus by Riemann-Zürneck (1991) and none is similar to $S$. galkini sp.n.

The present specimens are very similar to $\mathrm{Had}$ alanthus aff. knudseni: López-González et al., 2003. Almost all reported features including external ap- pearance, shape and distribution of tubercles, number of perfect mesenteries and distribution of gonads are identical. The total number of mesenteries and tentacles also appear to be similar, although the description of $H$. aff. knudseni is not quite clear in this respect. It is stated that the species has the same number of mesenteries distally and proximally, hexamerously arranged in four cycles. The total number of mesenteries is, therefore, 96. This number does not correspond to the reported number of tentacles, up to 140 in a large specimen, and the specimens either should have more mesenteries distally than proximally (as in the present specimens), or more than four cycles of mesenteries, at least in large specimens. Acontia have not been recorded in $H$. aff. knudseni, but in many deep water species the presence of acontia is not always easy to establish as they "are particularly liable to disintegrate during the process of sampling when discharging their nematocysts" (Riemann-Zürneck, 1997:372). The size ranges and distribution of nematocysts are virtually identical. Robust spirocysts of $H$. aff. knudseni are of the same type as those of the present specimens (not characteristic for the family Actinostolidae to which $H$. aff. knudseni was assigned). The material was collected in about the same depth and habitat (cold seeps, attached to Calyptogena shells). Thus, there is no doubt that $H$. aff. knudsen $i$ is conspecific with the present material.

Seepactis galkini sp.n. (including the specimens of $H$. aff. knudseni: López-González et al., 2003) is not conspecific with Hadalanthus knudseni Carlgren, 1956 and cannot be assigned to this monotypic genus. Hadalanthus knudseni is an ultra-abyssal species known from only three specimens collected in the Kermadec Trench, SW Pacific. Carlgren (1956) failed to find acontia in this species and assigned it to the Actinostolidae. The cnidae of H. knudseni were reported by Carlgren (1956) and LópezGonzález et al. (2003, type revision). Although the latter authors noted that the condition of the type specimens of $H$. knudseni does not allow obtaining enough measurements of cnidae for statistic analysis, the differences in cnidae between $H$. knudseni and S. galkini are obvious. In particular, columnar pmastigophores have not been reported in type specimens of H. knudseni (Carlgren, 1956, LópezGonzález et al., 2003). It is unlikely that they were overlooked since p-mastigophores are common in the present material and "common" to "very common" in the material identified as $H$. aff. knudseniby López-González et al. (2003: 230). Tentacle basitrichs of $H$. knudseni are of two size ranges (one size range in $S$. galkini sp.n.) and large basitrichs $(34-43 \times 3.0 \mathrm{~mm})$ are larger than those in any tissue of the present species. Hadalanthus knudseni apparently has sparse large and thick basitrichs in the 
tentacles $(48-53 \times 5 \mathrm{~mm})$ which are not present in the S. galkini sp.n. Further, according to Carlgren (1956) his species has the same number of mesenteries distally and proximally and the data he provided support this statement: a medium sized (more than $1.5 \mathrm{~cm}$ high) specimen of $H$. knudseni has three cycles of mesenteries ( $=48$ mesenteries) and 48 tentacles, and a larger $(3 \mathrm{~cm})$ specimen has the incomplete cycle of the mesenteries of the fourth order and, correspondingly, about 70 tentacles. In $S$. galkini sp.n. the mesenteries are more numerous distally than proximally and the total number of mesenteries (four and an incomplete fifth cycle) and tentacles (120 in $12 \mathrm{~mm}$ specimen) is significantly higher than in $H$. knudseni.

Seepactis galkini sp.n. is known only from cold seeps of the Eastern Pacific: Monterey Canyon (3028$3045 \mathrm{~m}$ ) and Middle American Trench off Manzanillo, Mexico (3354-3795 m). All known specimens were attached to bivalves of the family Vesicomyidae (Calyptogena sp. and Ectenagena extenta).

\section{Family Hormathiidae}

\section{Paraphelliactis Carlgren, 1928}

Three species were assigned to this genus: $P$. spinosa Carlgren, 1928, P. michaelsarsi Carlgren, 1934, and P. pabista Dunn, 1982. Carlgren (1942) used two features to distinguishParaphelliactisfrom Phelliactis: a different arrangement of the radial muscles of the oral disc, and a development of probably more mesenteries at the margin than at the limbus. Riemann-Zürneck (1973) revised the genus Phelliactis and synonymized Paraphelliactis with Phelliactis based on the fact that the appearance of the radial muscles is a variable feature that cannot be used to separate the genera. She, however, never discussed the second, more reliable feature, a relation of the number of the tentacles (and hence the number of the mesenteries at the margin) to the number of the mesenteries at the limbus. According to Carlgren (1942) the type species of Phelliactis (P. hertwigi Simon, 1892) always has fewer tentacles than the mesenteries at the base (148 tentacles and 166 mesenteries counted in one specimen). The same arrangement is characteristic for some other species of Phelliactis, e.g.P. robusta Carlgren, 1928 (Carlgren, 1942, Molodtsova et al, in preparation). In the type species of Paraphelliactis ( $P$. spinosa Carlgren, 1928) Carlgren (1942) counted 168 tentacles but only 150 mesenteries proximally, so in this species the mesenteries probably grow from the disc downward. Riemann-Zürneck (1973) supposed that Paraphelliactis spinosa may be conspecific with Phelliactis robusta. However, they have a different appearance (e.g. characteristic large and smooth tubercles in $P$. robusta and acuminated tubercles in $P$. spinosa) and do not appear to be identical. The taxonomic position of the second species assigned to Paraphelliactis, P. michaelsarsi, is problematic. In a poorly preserved specimen Carlgren (1934) documented a significant difference in the number of mesenteries at the limbus (114) and margin (about 140 ), but a recently recorded specimen from the Mid-Atlantic ridge has almost the same number of mesenteries distally and proximally (156 mesenteries distally, 160 proximally) (Molodtsova et al, in preparation). This species has been redescribed by Riemann-Zürneck (1986), who, unfortunately, did not count the mesenteries in her specimens.

In Paraphelliactis pabista (see below) the mesenteries of the fifth cycle appear at the margin and grow downward, and, in some specimens, the mesenteries are significantly more numerous distally than proximally, e.g. 172 mesenteries at the margin and 98 near the limbus (specimen IORAS IV-9-Act07-010) and therefore this species does not appear to be congeneric with Phelliactis. Thus, although the status of the genus Paraphelliactis remains unclear, in the present paper we follow Dunn (1982) in assigning this species to Paraphelliactis.

\section{Paraphelliactis pabista Dunn, 1982}

Figs. 4D, 5.

Paraphelliactis pabista Dunn, 1982: 51.

Material examined. Guaymas Basin: st. 2360, two specimens; st. 2362 , one specimen; st. 4714 , three specimens.

Description. According to the collector the living specimens have a circular oral disc up to $15 \mathrm{~cm}$ in diameter and short tentacles. All preserved specimens are very similar and have a characteristic cup shaped body (Fig. 4D) $54-71 \mathrm{~mm}$ high, 44-73 mm in the greatest diameter distally and $20-27 \mathrm{~mm}$ diameter near the base. The column is divided into a scapus and a short scapulus. Scapus covered with tubercles arranged into 24 regular longitudinal rows, they become smaller toward the base and disappear near the limbus. The most distal tubercles are larger, up to $5 \mathrm{~mm}$ in height and $10 \mathrm{~mm}$ in basal diameter, conical, with pointed, often turned up apexes. Scapus is covered by dark cuticle which remains only in grooves and often on the sides of tubercles in preserved specimens. Scapulus is almost smooth. The tentacles are arranged in several cycles at very periphery of the oral disc, with aboral mesogloeal thickenings at base, 105 and 141 tentacles counted in two specimens. The number of the tentacles is almost equal or slightly fewer than the number of the mesenteries at margin, but usually larger than mesenteries at base. The radial ectodermal muscles of the oral 

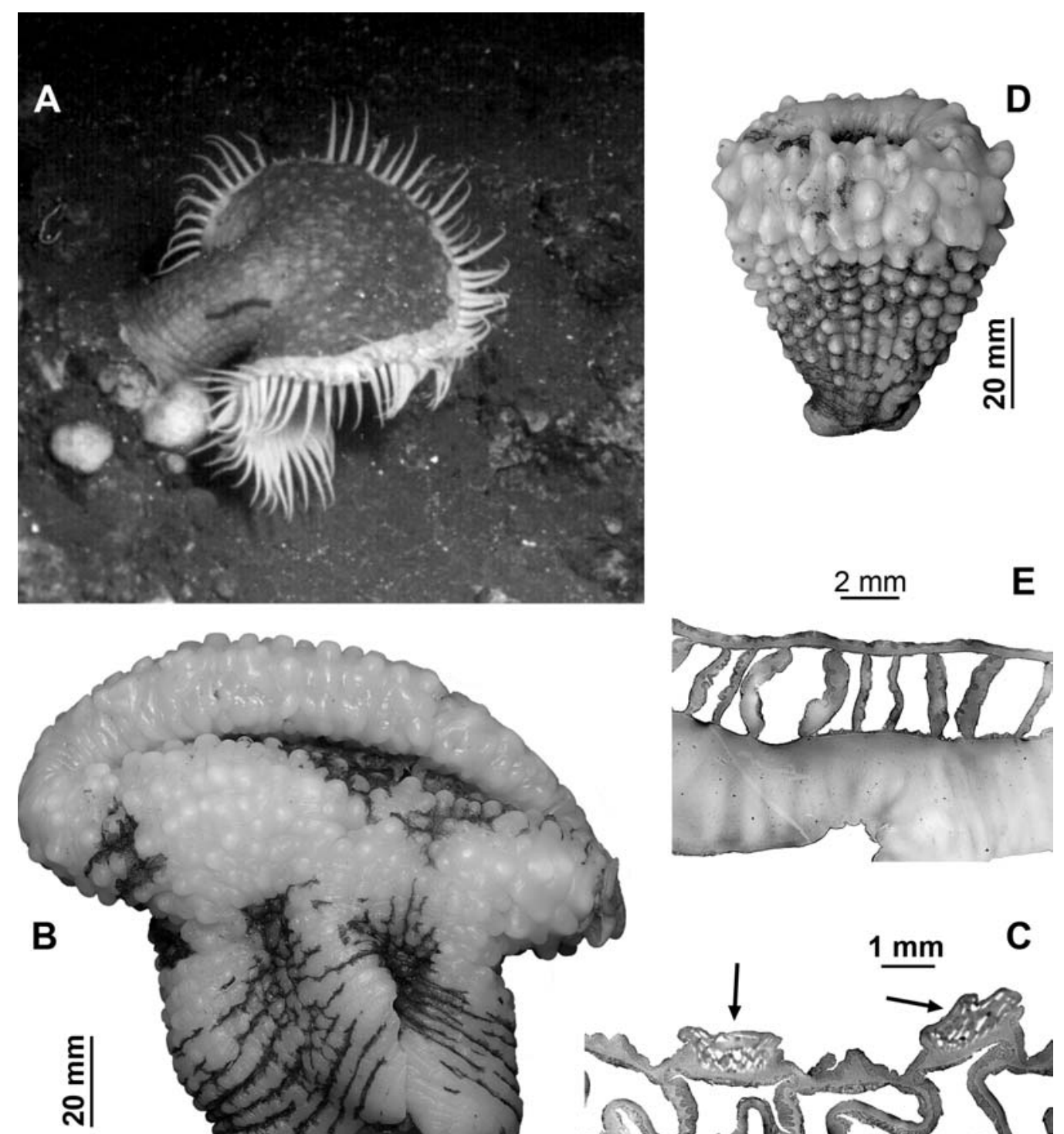

B
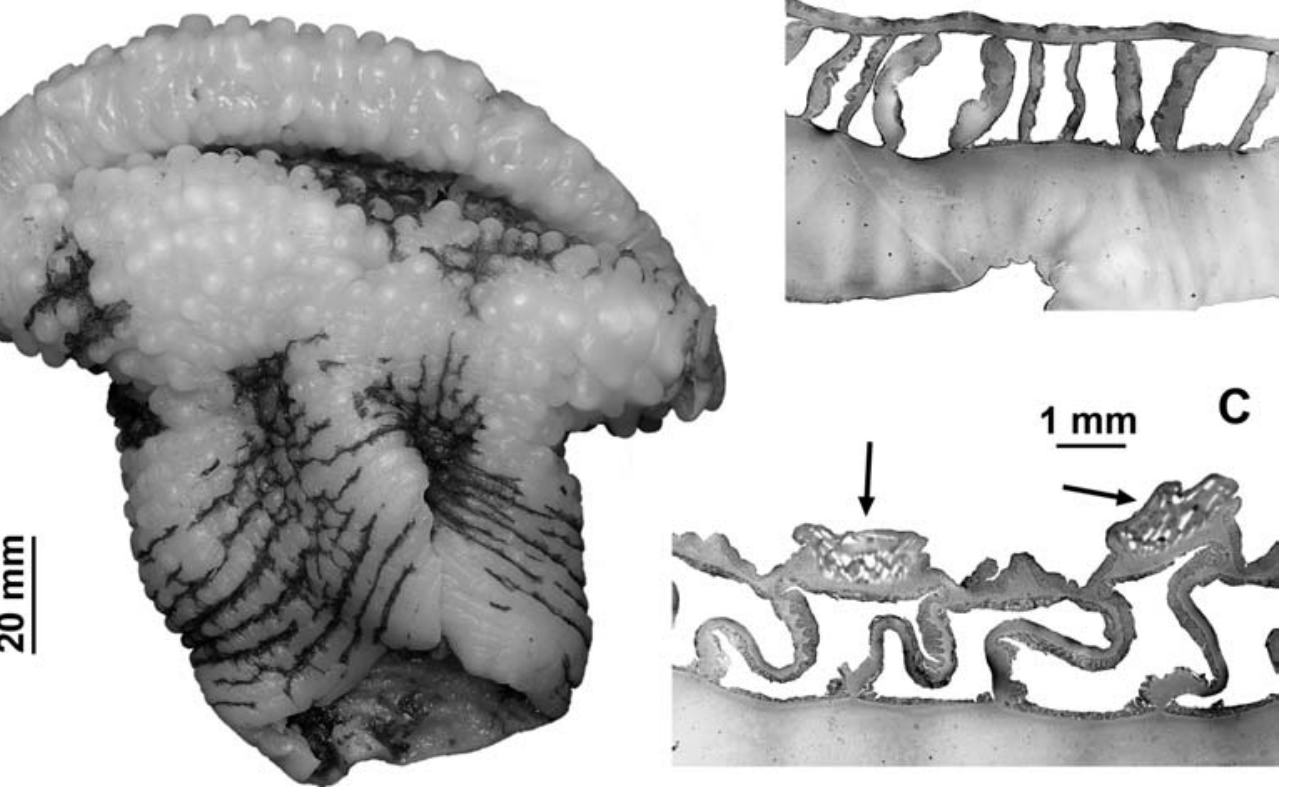

Fig. 4. Phelliactis callicyclus Riemann-Zürneck, 1973 (A-C) and Paraphelliactis pabista Dunn, 1982 (D, E). A - in situ photo of the living specimen (Guaymas Basin); B - preserved specimen; C - transverse section of the oral disc, note that mesogloea is much thicker over endocoels (arrows); D - preserved specimen; E — transverse section of the oral disc, note the same thickness of the mesogloea is over endocoels and exocoels.

Рис. 4. Phelliactis callicyclus Riemann-Zürneck, 1973 (А-C) и Paraphelliactis pabista Dunn, 1982 (D, E). $\mathrm{A}$ — фотография живого экземпляра (бассейн Гуаймас); В — зафиксированный экземпляр; $\mathrm{C}$ — поперечный срез через оральный диск, мезоглея значительно толще над эндоцелями (стрелки); D — зафиксированный экземпляр; E - поперечный срез через оральный диск, мезоглея одинаковой толщины над эндоцелями и экзоцелями. 


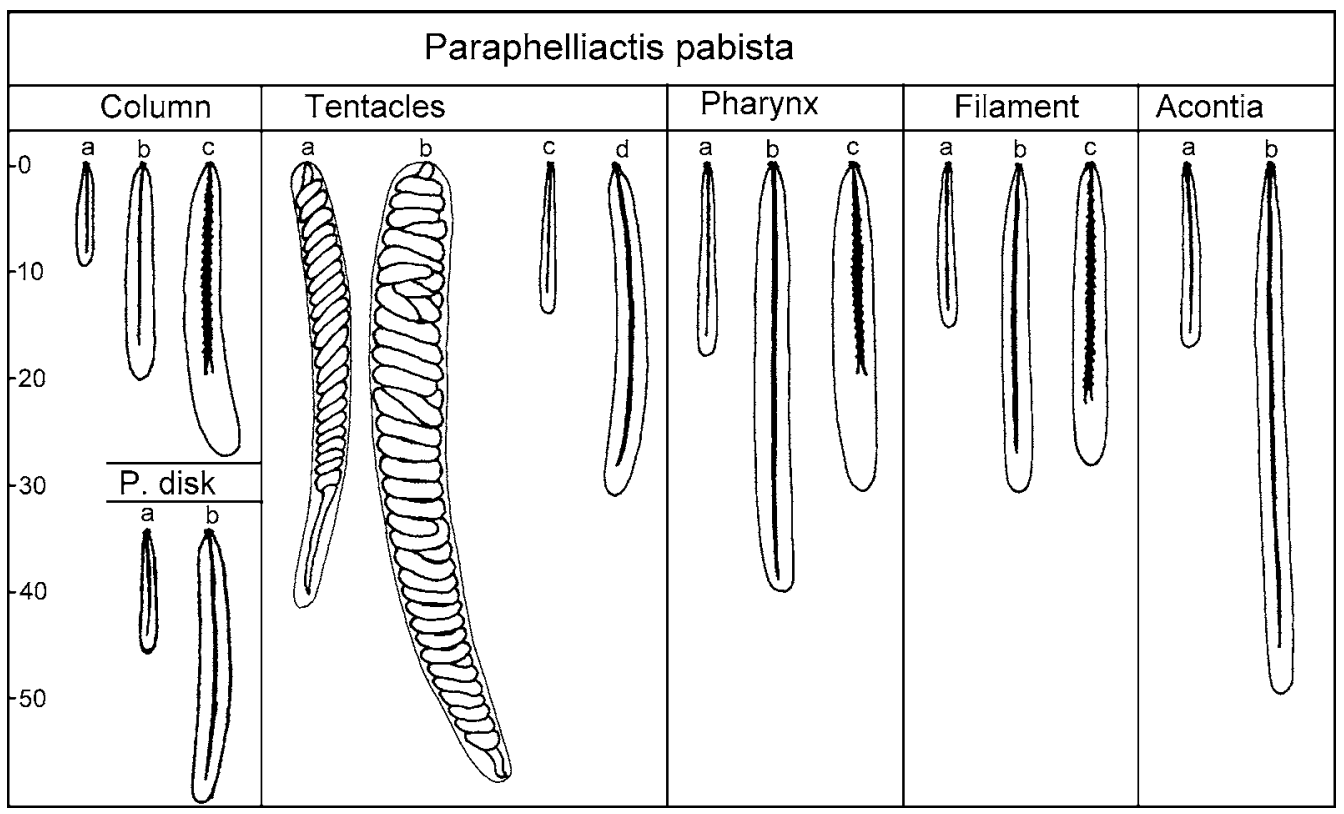

Fig. 5. Paraphelliactis pabista Dunn, 1982, cnidom.

Рис. 5. Paraphelliactis pabista Dunn, 1982, книдом.

disc are equally developed and the thickness of the mesogloea is the same in parts corresponding to exocoels and endocoels (Fig. 4E). The mesogloea in the middle of column is about $5 \mathrm{~mm}$ thick. Mesenteries are arranged in five cycles, the fifth cycle is incomplete. Mesenteries of the fifth cycle are present only between the mesenteries of the third and fourth cycles. Mesenteries of the first-fourth orders are present along the whole length of the column in all specimens. Mesenteries of the fifth order appear at the margin and grow downward. The mesenteries may be slightly or significantly more numerous distally than proximally depending on the number and degree of development of the mesenteries of the fifth order. The largest difference is in a specimen IORAS IV-9-Act-07-010 (98 mesenteries at base, 128 in the middle of column and 172 near the margin). The difference is less evident in the specimens with few mesenteries of the fifth cycle, e.g. 96 mesenteries at base and 101 near the margin (IORAS IV-9-Act-07007) or 96 at base and 110 at margin (IORAS IV-9Act-07-008). Other anatomical characters are in good agreement with the original description.

Size and distribution of cnidae (letters in brackets refer to Fig. 5, all measurements in microns; $\mathrm{N}$ is the proportion of examined specimens that had a particular type of cnidae):

Pedal disc: basitrichs (a) - 11-15x1.5-2 (very rare), $\mathrm{N}=3 / 3$; basitrichs (b) $-22-31 \times 2.5-3.5$ (common), $\mathrm{N}=3 / 3$.
Column: basitrichs (a) $-8-15 \times 1.5-2$ (rare), $\mathrm{N}$ $=3 / 3$; basitrichs $(\mathrm{b})-18-24 \times 2.5-3.5($ common $), \mathrm{N}$ $=3 / 3$; p-mastigophores B (c) $-23-34 \times 3-4.5$ (rare), $\mathrm{N}=3 / 3$.

Tentacles: gracile spirocysts (a) $-24-54 \times 3-$ 5.5 (numerous), $\mathrm{N}=3 / 3$; robust spirocysts (b) -22 $63 \times 3.5-10$ (numerous), $\mathrm{N}=3 / 3$; basitrichs (c) $13-22 \times 1.5-2.5$ (rare), $\mathrm{N}=3 / 3$; basitrichs (d) $-21-$ $38 \times 2.5-3$ (common), $\mathrm{N}=3 / 3$.

Actinopharynx: basitrichs (a) - 17-22 x2-2.5 (very rare), $\mathrm{N}=2 / 3$; basitrichs (b) $-28-46 \times 3-3.5$ (numerous), $\mathrm{N}=3 / 3$; p-mastigophores $\mathrm{B}$ (c) - 25$43 \times 3-5$ (common), $\mathrm{N}=3 / 3$.

Filaments: basitrichs (a) $-12-20 \times 1.5-2$ (common), $\mathrm{N}=3 / 3$; basitrichs (b) $-23-34 \times 2.5-3$ (very rare), $\mathrm{N}=3 / 3$; p-mastigophores $\mathrm{B}(\mathrm{c})-23-38 \times 3-$ 4.5 (numerous), $\mathrm{N}=3 / 3$.

Acontia: basitrichs (a) - 17-22x1.5-2 (common), $\mathrm{N}=2 / 2$; basitrichs (b) $-44-55 \times 3-3.5$ (very numerous), $\mathrm{N}=2 / 2$.

Bulbous nematocysts characteristic for medusae were detected on smears of filaments of some specimens (supporting the suggestion of Dunn (1982) that the species feeds on medusae).

Habitat. According to the collector of the present specimens this species is characteristic for "background" fauna of hydrothermal vents. The oral disc is bent to two catching lobes oriented toward the water current. The specimens occur $15-20 \mathrm{~m}$ from each other, often in shallow depressions and are 
occasionally recorded standing on the oral disc with the base directed upward, or rolling on the side on the bottom. One specimen was attached to a Calyptogena shell.

Remarks. Paraphelliactis pabista, known previously only from its original description, is based on numerous specimens recorded from Pacific coasts of Canada. The present specimens agree closely with the original description, although we found more types of cnidae in different tissues than reported by Dunn (1982). In particular, the acontia contain two types of basitrichs (as in most Hormathiidae) and pmastigophores are present in filaments, pharynx and column (as in most species of Phelliactis, Paraphelliactis and related genera). The arrangement of the mesenteries, which are more numerous distally than proximally, is also in agreement with the previously described specimens. The statement of Dunn (1982) that the species has an equal number of mesenteries throughout the length of the animal, and at the same time the mesenteries are fewer than the tentacles cannot be correct. In this group of sea anemones only one tentacle arises from each endoand exocoel, and the number of tentacles cannot be larger than the number of mesenteries at the oral disc. Thus, if the tentacles are more numerous than the mesenteries in the examined region of the body the specimen must have additional mesenteries distally.

\section{3}

Phelliactis callicyclus Riemann-Zürneck,

$$
\text { Figs } 4 \mathrm{~A}-\mathrm{C}, 6 .
$$

Phelliactis callicyclus Riemann-Zürneck, 1973: 313

Material examined. Guaymas Basin, st. 4714, one specimen.

Description. The living specimen has a cylindrical column and a very wide oral disc bent into two lobes, dorsal and ventral (Fig. 4A). The preserved specimen is large, $186 \mathrm{~mm}$ high and $134 \mathrm{~mm}$ in greatest diameter distally. The column is more or less the same diameter throughout its length $(73 \mathrm{~mm})$ and its distal part significantly and abruptly expanded (Fig. 4B). The oral disc is folded into two unequal lobes. The column is divided into a scapus and a short $(1-1.5 \mathrm{~cm})$ scapulus. The scapus is covered with relatively small crowded hemispherical tubercles which become smaller and flattened in the proximal half of the column and disappear near the limbus. In living specimen the cuticular covering of the scapus appears to be darker between and paler on tubercles, in preserved specimen the cuticle remains only in grooves. Scapulus has numerous scapular ridges, each with one to three well marked tubercles along its length. The tentacles are arranged in several cycles at very periphery of the oral disc, about 186 in number, all with aboral mesogloeal thickenings at base. The mesogloea and radial muscles of the oral disc unequally developed in parts corresponding to exocoels and endocoels: radial muscles are weaker and mesogloea is significantly thicker over the endocoels than over the exocoels (Fig. 4C). Mesogloea of column is about $5 \mathrm{~mm}$ thick. Mesenteries are in five cycles, the fifth cycle is complete and the mesenteries of the fifth cycle are present along the whole length of column: 192 mesenteries were counted in the middle of column and 194 near the margin. Only mesenteries of first cycle (six pairs) are perfect. Mesenteries of the first and fifth cycle are sterile, other mesenteries fertile, with oocytes about 0.25 $\mathrm{mm}$ in diameter. Other anatomical characters are in good agreement with the original description.

Size and distribution of cnidae (letters in brackets refer to Fig. 6, all measurements in microns):

Pedal disc: basitrichs (a) - 11-18x1.5-2 (rare); basitrichs (b) - 25-41×3.5-4 (common).

Column: basitrichs (a) - 11-15x1.5-2 (rare); basitrichs (b) - 20-29x3-4 (common); p-mastigophores B (c) - 31-43x4-5.5 (rare).

Tentacles: gracile spirocysts (a) - 23-62x3-7 (numerous); robust spirocysts (b) - 36-74x5-11 (numerous); basitrichs (c) - 17-23x1.5-2 (rare); basitrichs (d) - 33-52x2.5-3.5 (common).

Actinopharynx: basitrichs (a) - 17-23x1.5-2 (very rare); basitrichs (b) - 39-50x3-4 (numerous); p-mastigophores B (c) - 29-41x4-5 (common).

Filaments: basitrichs (a) - 15-24x1.5-2 (common); basitrichs (b) - 45-64×3-4 (rare); p-mastigophores B (c) - 31-47x3.5-5 (common).

Acontia: basitrichs (a) - 17-27x2 (common); basitrichs (b) - 49-60x3.5-4 (very numerous).

Large basitrichs in the filaments are of the same length as large basitrichs in the acontia. Bulbous nematocysts characteristic for medusae were detected on some smears of filaments, so the species probably feeds on medusae.

Remarks. This species was known previously only from original description based on four specimens collected in the SW Atlantic at 800 and 1220 $\mathrm{m}$. Although the assignment of the present Pacific specimen to a species described from the Atlantic is not obvious, we failed to find any reliable characters that could separate them. Pacific specimen (with small rounded tubercles, flattened and inconspicuous on the proximal half of the column) resembles the holotype of this species (Riemann-Zürneck, 1973, Fig. 14c). Internal structure is identical and size and distribution of cnidae agree very well. The main distinguishing characters of the present species are the presence of six pairs of perfect mesenteries and a complete fifth cycle of mesenteries. The only other species of this genus in which the fifth cycle of mesenteries is complete is $P$. capricornis RiemannZürneck, 1973, which differs in having additional 


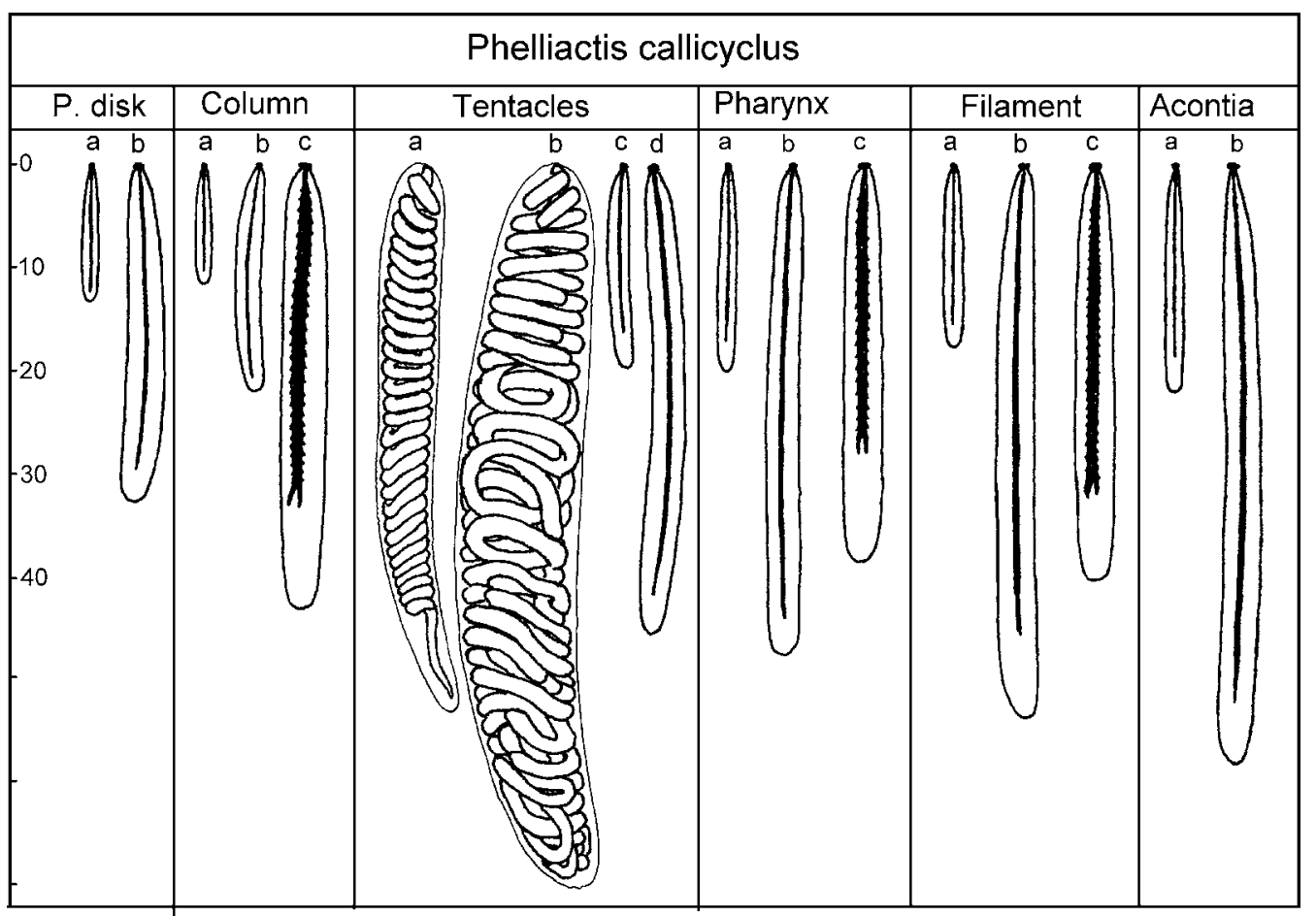

Fig. 6. Phelliactis callicyclus Riemann-Zürneck, 1973, cnidom.

Рис. 6. Phelliactis callicyclus Riemann-Zürneck, 1973, книдом.

unpaired perfect mesenteries. Large basitrichs in acontia are also characteristic for $P$. callicyclus, they are larger than in most (although not all) other Phelliactis species.

Phelliactis hydrothermala Sanamyan et Sanamyan sp.n.

Figs 7, 8 .

Material examined. EPR, $21^{\circ} \mathrm{N}$, st. 2369 , one specimen.

Description. External structure. Formalin preserved specimen is about $10 \mathrm{~cm}$ in height and greatest diameter, with wide pedal disc spread into thin membrane broader than the proximal portion of the column (Figs 7G, H). The column is divided into scapus and scapulus. The scapus is rough, covered with continuous layer of thin brownish cuticle and pyramidal tubercles arranged into about 30 not very regular longitudinal rows. The tubercles are larger in the distal portion of the scapus where they attain about $1 \mathrm{~cm}$ in height and diameter, and become smaller toward the base. The cuticle covering tubercles is darker and slightly thicker than on the rest of scapus, up to $0.05 \mathrm{~mm}$, and the cuticle often forms dark pointed tip on the summit of tubercle. The scapulus, $2 \mathrm{~cm}$ wide, is clearly demarcated from the scapus by the absence of cuticle and has numerous low longitudinal ridges, probably appearing as a result of contraction, otherwise its surface is smooth, without tubercles. The oral disc is folded in directive direction and mesenterial insertions are visible on its surface as shallow radial furrows. The tentacles, 144 in number, are not completely covered by the upper part of column in preserved specimen. They are long, up to $4 \mathrm{~cm}$, almost cylindrical or slightly tapering to the top and arranged in several cycles at outer third of the oral disc. Basal mesogloeal thickenings are conspicuous on the aboral sides of all tentacles (Figs 7B, F), and thickened mesogloea occasionally continues from the tentacle base to about half of its length.

Internal structure. Mesogloea of the body homogenous, firm and thick, up to $5 \mathrm{~mm}$ between the tubercles and up to $1 \mathrm{~cm}$ on the tubercles in the middle part of column, about the same thickness in scapus and scapulus. Ectoderm is very thin, about $0.05 \mathrm{~mm}$ thick, the thickness is the same on and between the tubercles. The mesogloeal sphincter is not strong, alveolar, with clear limits, occupies almost whole breadth of the mesogloea in the distal 




Fig. 7. Phelliactis hydrothermala sp.n., holotype (ZMMU Ec-107).

A - columnar tubercles; B - tentacles with mesogloeal thickenings; C - cross section of column; D - marginal sphincter; $\mathrm{E}$ - transverse section of the oral disc; $\mathrm{F}$ - cross section of the tentacle showing mesogloeal thickening at base; $\mathrm{G}, \mathrm{H}$ - external appearance.

Рис. 7. Phelliactis hydrothermala sp.n., голотип (ZMMU Ec-107).

A — колумнарные туберкулы; В - щупальца с мезоглеальными утолщениями; C — поперечный срез колумна; $\mathrm{D}$ - маргинальный сфинктер; E - поперечный срез через оральный диск; $\mathrm{F}$ - поперечный срез щупальца, показывающий мезоглеальное утолщение у основания; G, H - внешний вид. 


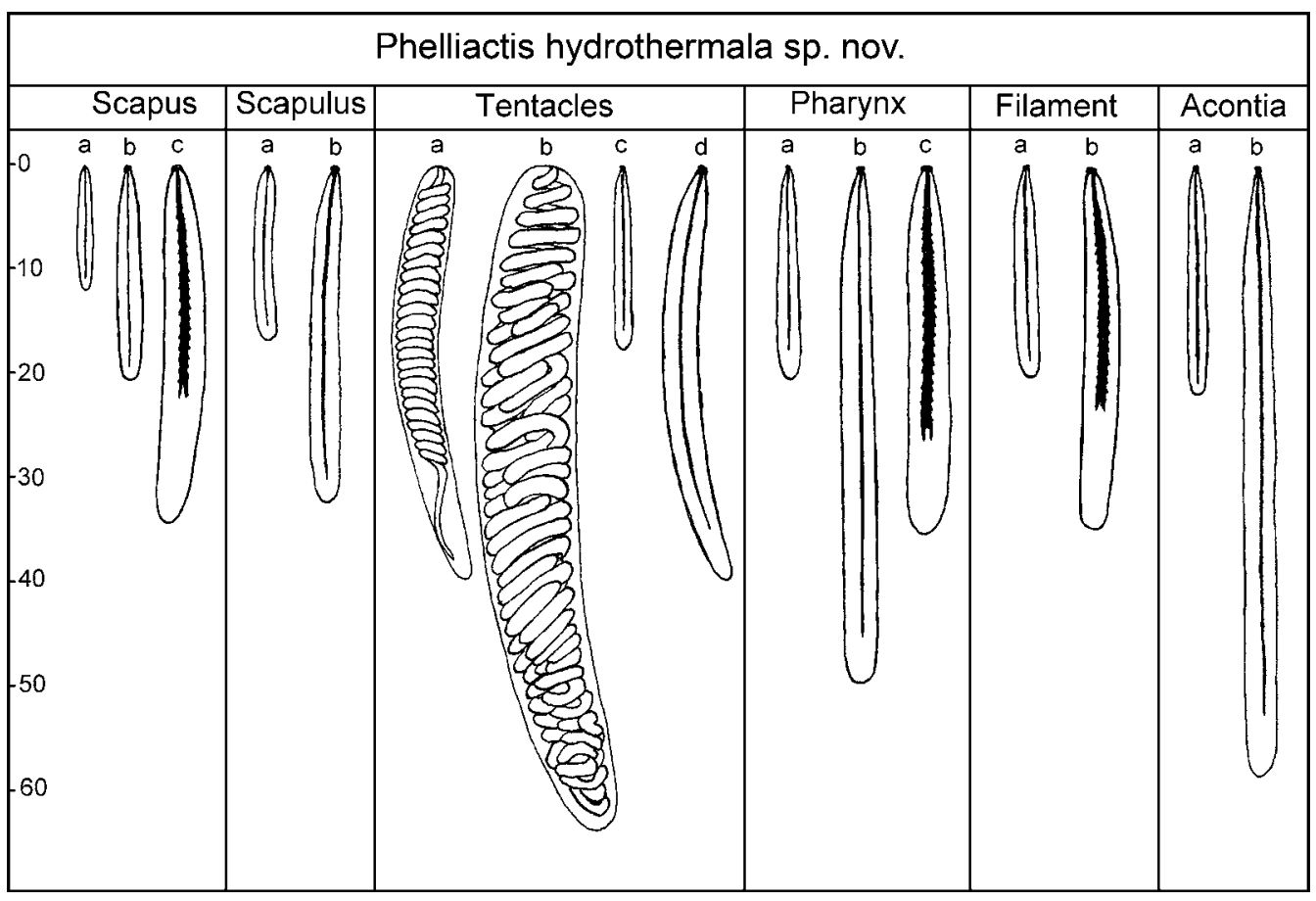

Fig. 8. Phelliactis hydrothermala sp.n., cnidom. Рис. 8. Phelliactis hydrothermala sp.n., книдом.

part of the scapulus, diminishes proximally and continues to the distal part of the scapus. Muscular alveoli on sections are spaced and arranged into several longitudinal bands (Fig. 7D). Longitudinal muscles of the tentacles and radial muscles of the oral disc are ectodermal and weak. The radial muscles of the oral disc are equally developed and the thickness of the mesogloea is the same in parts corresponding to exocoels and endocoels (Fig. 7E). Long actinopharynx almost reaches the bottom of the scapus. Two siphonoglyphs supported by directives are of nearly the same thickness as the rest of actinopharynx, about $1 \mathrm{~mm}$ thick. Mesenteries are arranged hexamerously in five cycles, the last cycle incomplete: $6+6+12+24+32$ pairs ( 160 mesenteries) are in the proximal half of column. If only one pair of the mesenteries of the fifth cycle is present in the exocoels of the third order, this pair more often is placed between the mesenteries of the third and fourth cycles. Only mesenteries of the first cycle (6 pairs) are perfect. Mesenteries of the first cycle are sterile; other mesenteries, except for the smallest ones, are fertile. Acontia well developed. Retractor muscles are weak, diffuse, extending along almost the whole length of the mesentery on transverse sections. Parietobasilar muscles poorly developed.

Size and distribution of cnidae (letters in brackets refer to Fig. 8, all measurements in microns; $\mathrm{N}$ is the proportion of examined specimens that had a particular type of cnidae):

Scapus: basitrichs (a) $-10-16 \times 1-2$ (rare); basitrichs (b) - 17-26x2.5-3 (common); p-mastigophores B (c) - 31-41x3.5-4.5 (rare).

Scapulus: basitrichs (a) - 14-18x1.5-2 (rare); basitrichs (b) $-25-35 \times 3-3.5$ (common).

Tentacles: gracile spirocysts (a) $-32-65 \times 4-$ 6.5 (numerous); robust spirocysts (b) $-20-77 \times 5-$ 11 (numerous); basitrichs (c) - 15-21x1.5-2 (very rare); basitrichs (d) - 29-50x2.5-3.5 (common).

Actinopharynx: basitrichs (a) $-20-22 \times 2-2.5$ (very rare); basitrichs (b) - 40-53×3.5-4.5 (common); p-mastigophores B (c) - 31-36x4-5 (rare).

Filaments: basitrichs (a) - 19-22×2-2.5 (common); p-mastigophores B (c) - 33-37x3.5 (common).

Acontia: basitrichs (a) - 22-28x2-2.5 (common); basitrichs (b) - 45-60x3-3.5 (very numerous).

Habitat. According to the collector this species occurs in the zone of black and white smokers and is characteristic for "background" fauna of hydrothermal vents. The specimen was attached to a piece of fresh black lava.

Remarks. The species is characterized by its pyramidal columnar tubercles arranged in longitudinal rows, presence of only six pairs of perfect mesen- 
teries, incomplete fifth cycle of mesenteries, and strong mesogloeal thickenings on the aboral sides of the tentacles. As in most Phelliactis species the mesenteries are somewhat more numerous proximally than distally. Internally the present species resembles $P$. robusta and $P$. somaliensis Carlgren, 1928. Phelliactis somaliensis is known only from its original description based on several specimens from the Indian Ocean. It is much smaller than P. hydrothermala sp.n. and has much smaller nematocysts in acontia. Phelliactis robusta is known from several records in Atlantic where appears to be rather common. Externally it differs quite markedly from $P$. hydrothermala sp.n., the tubercles are typically smooth, large, crowded, and not arranged in rows, and mesogloeal thickenings at tentacle bases are usually not large. Phelliactis callicyclus also has only six pairs of perfect mesenteries, but fifth cycle of mesenteries is complete, tubercles are relatively small, crowded and hemispherical, not acuminated, and an external appearance is entirely different. Other known species of Phelliactis do not appear to be similar, they either have additional perfect mesenteries (nine species belonging to a group of $P$. hertwigi, see Riemann-Zürneck, 1973), or 12 pairs of perfect mesenteries ( $P$. gigantea (Carlgren, 1941), $P$. lophohelia Riemann-Zürneck, 1973, P. americana Widersten, 1976).

In its acuminated tubercles and six pairs of perfect mesenteries $P$. hydrothermala sp.n. resemblesParaphelliactis spinosa which, unlike the present species, has more mesenteries distally than proximally, tubercles are not in rows and nematocysts in acontia are significantly smaller than in P. hydrothermala sp.n.

In general shape of the body with thin, widely expanded pedal disc and in the shape and distribution of the pyramidal tubercles the present species is very similar to Hormathia spinosa (Hertwig, 1882) (see Hertwig, 1882, Plate 1, Fig. 3, and Rodriguez, Lopez-Gonzales, 2001, Fig. 6C,D, [type revision]). Anatomy of $H$. spinosa has been carefully described by Hertwig (1882) who found only four cycles of mesenteries and 96 tentacles without mesogloeal thickenings. Both features are characteristic for Hormathia and not for Phelliactis and an assignment of Hertwig's species to Hormathia appears to be correct.

\section{Family Actinoscyphiidae}

\section{Cyananthea Doumenc et Van-Praët, 1988}

Definition. Actinoscyphiidae (?) with broad adherent pedal disc. Column smooth, without clear division in scapus and scapulus. Cinclides present at least in stronger endocoels. Sphincter mesogloeal, strong. Longitudinal muscles of the tentacles and radial muscles of the oral disc ectodermal to mesoectodermal. Mesenteries more numerous distally than proximally, hexamerously arranged, two first cycles (12 pairs) perfect. Two siphonoglyphs and two pairs of directives. Retractors diffuse. All stronger mesenteries fertile. Acontia absent (?). Cnidom: robust and gracile spirocysts, heterotrichs, basitrichs and p-mastigophores B. No p-mastigophores A.

\section{Cyananthea hydrothermala Doumenc et} Van-Praët, 1988

Figs 9, 10.

Cyananthea hydrothermala Doumenc, Van-Praët, 1988: 65; Desbruyères, Segonzac, 1997: 28.

Material examined. EPR, $9^{\circ} \mathrm{N}$, st. 4623 , two specimens, one on a piece of black volcanic glass (obsidian) (IORAS IV-9-Act-07-013 and 014). EPR, $21^{\circ} \mathrm{N}$, st. 4679 , one specimen on a stone collected 1.5 $\mathrm{m}$ from the top of the hydrothermal building (IORAS IV-9-Act-07-015).

Description. External structure. The specimen from EPR, $21^{\circ} \mathrm{N}$ is strongly damaged; two specimens from EPR, $9^{\circ} \mathrm{N}$ are in good condition. The larger specimen (IORAS IV-9-Act-07-013) $25 \mathrm{~mm}$ high and $30 \mathrm{~mm}$ in the greatest diameter has cylindrical body slightly compressed in directive plane. Tentacles are completely covered by upper part of column (Fig. 10A). The column of another specimen (IORAS IV-9-Act-07-014) (19 mm high and $20 \mathrm{~mm}$ in greatest diameter) is much broader distally than proximally and the tentacles are exposed (Fig. 10B). Distal part of the column is marked by a marginal circumferential ridge. The column of the preserved specimens is finely wrinkled on proximal half and almost smooth on the upper portion, without any traces of cuticle. A ring of 12 cinclides is present in the upper portion of column some distance (up to 1 $\mathrm{cm}$ ) down from the margin, exactly at the proximal end of the marginal sphincter (Fig. 10C). Each cinclis is associated with primary or secondary endocoel, and appear externally as rather unclear perforated tubercle or papilla situated in a shallow depression of mesogloea (Fig. 10D). Cinclides are difficult to observe, although those associated with the directives are better visible, with the tubercle about $1 \mathrm{~mm}$ diameter and a perforation up to $0.1 \mathrm{~mm}$ diameter. Although the column is not separated into distinct regions, its part above the ring of cinclides has slightly thicker mesogloea and somewhat different texture from that of the proximal portion, suggesting the scapus and scapulus may present. Tentacles are long, cylindrical or slightly tapering, the outer much shorter than the inner, numerous, more than 110 are visible externally in a less contacted specimen. 


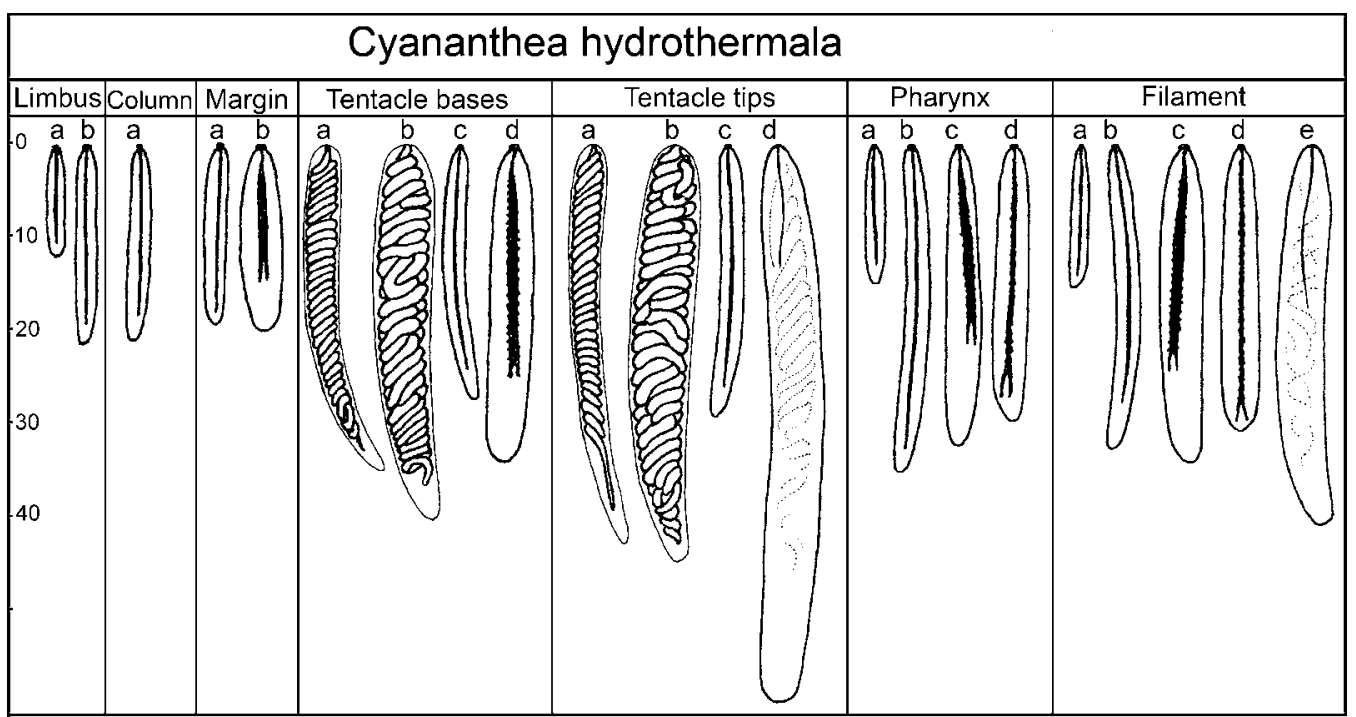

Fig. 9. Cyananthea hydrothermala Doumenc et Van-Praët, 1988, cnidom.

Pис. 9. Cyananthea hydrothermala Doumenc et Van-Praët, 1988, книдом.

Internal structure. Ectoderm is thin, lost on some parts of column. Mesogloea is about $2 \mathrm{~mm}$ thick at the margin, narrowing to $1 \mathrm{~mm}$ just below the sphincter (on the level of the ring of cinclides), and up to $1.2 \mathrm{~mm}$ in the proximal portion of the column.

The main part of rather strong alveolar mesogloeal sphincter occupies about half the width of the mesogloea and situated close to the endoderm. Longitudinal muscles of the tentacles and radial muscles of the oral disc are ectodermal. Long actinopharynx has clear longitudinal ridges of thickened mesogloea corresponding to insertion of perfect mesenteries and two deep thick-walled siphonoglyphs supported by directives. The ectoderm of the pharynx is darkbrown, siphonoglyphs are whitish. Mesenteries are arranged hexamerously in five cycles, fifth cycle is incomplete and present only in distal part of the column. In one specimen (IORAS IV-9-Act-07-014) 94 mesenteries $(6+6+12+23$ pairs $)$ were counted proximally and 142 mesenteries $(6+6+12+24+23$ pairs $)$ distally. A half of another specimen (IORAS IV-9Act-07-013) has 48 mesenteries proximally and 76 distally, of which one pair belongs to sixth cycle. Mesenteries of the first and the second order (12 pairs) are perfect. Only mesenteries of the first three cycles are fertile. Mesogloea of the mesenteries is thick, the retractor muscles are weak and diffuse, occupy most length of the mesentery on transverse section (Fig. 10D). Parietobasilar muscles hardly discernible. We failed to find acontia in any specimen.

Size and distribution of cnidae (letters in brackets refer to Fig. 9, all measurements in microns; $\mathrm{N}$ is the proportion of examined specimens that had a particular type of cnidae):
Limbus: basitrichs (a) $-12-14 \times 2$ (very rare), $\mathrm{N}=$ $1 / 2$; basitrichs (b) $-16-26 \times 2-3$ (common), $N=2 / 2$. Column: basitrichs (a) - 19-25×2-3 (common), $\mathrm{N}=2 / 2$.

Margin: basitrichs (a) $-18-27 \times 2-3$ (common), $\mathrm{N}=3 / 3$; p-mastigophores B (b) - 20-26x4-5.5 (very rare), $\mathrm{N}=3 / 3$.

Tentacle base: gracile spirocysts (a) - $22-$ $45 \times 2.5-4.5$ (common), $\mathrm{N}=3 / 3$; robust spirocysts (b) - 19-70x3.5-9 (numerous), $\mathrm{N}=3 / 3$; basitrichs (c) - 20-35x2-3.5 (common), $\mathrm{N}=3 / 3$; p-mastigophores $\mathrm{B}(\mathrm{d})-22-38 \times 3.5-6$ (very numerous), $\mathrm{N}=$ $3 / 3$.

Tentacle tips: gracile spirocysts (a) - 24-76×36 (numerous), $\mathrm{N}=2 / 2$; robust spirocysts (b) $-21-$ 60x4-8 (common), $\mathrm{N}=2 / 2$; basitrichs (c) $-22-$ $41 \times 2-3$ (common), $\mathrm{N}=2 / 2$; heterotrichs (d) -39 $72 \times 4-7$ (common), $\mathrm{N}=2 / 2$.

Actinopharynx: basitrichs (a) $-12-19 \times 2-2.5$ (rare), $\mathrm{N}=3 / 3$; basitrichs (b) - (21)27-37x2-3 (common), $\mathrm{N}=3 / 3$; p-mastigophores $\mathrm{B}$ (c) - 26$37 \times 3.5-5$ (numerous), $\mathrm{N}=3 / 3$; $\mathrm{p}$-mastigophores $\mathrm{B}$ (d) $-26-36 \times 2.5-5$ (common), $\mathrm{N}=2 / 3$.

Filaments:basitrichs (a) - 12-20x1.5-2.5 (rare), $\mathrm{N}=3 / 3$; basitrichs (b) $-26-35 \times 2.5-3$ (very rare), $\mathrm{N}=3 / 3$; p-mastigophores $\mathrm{B}$ (c) - 26-40×3.5-5 (numerous), $\mathrm{N}=3 / 3$; $\mathrm{p}$-mastigophores $\mathrm{B}(\mathrm{d})-25-$ $37 \mathrm{x} 4-5$ (common), $\mathrm{N}=2 / 3$; heterotrichs (e) $-36-$ $45 \times 4.5-6.5$ (common), $\mathrm{N}=2 / 3$.

P-mastigophores are extremely numerous on the bases of the tentacles, but are sparse distally. On exploded capsules of this type the thread is either absent or short, up to 60 microns. Spirocysts are also unequally distributed: robust spirocysts are signifi- 

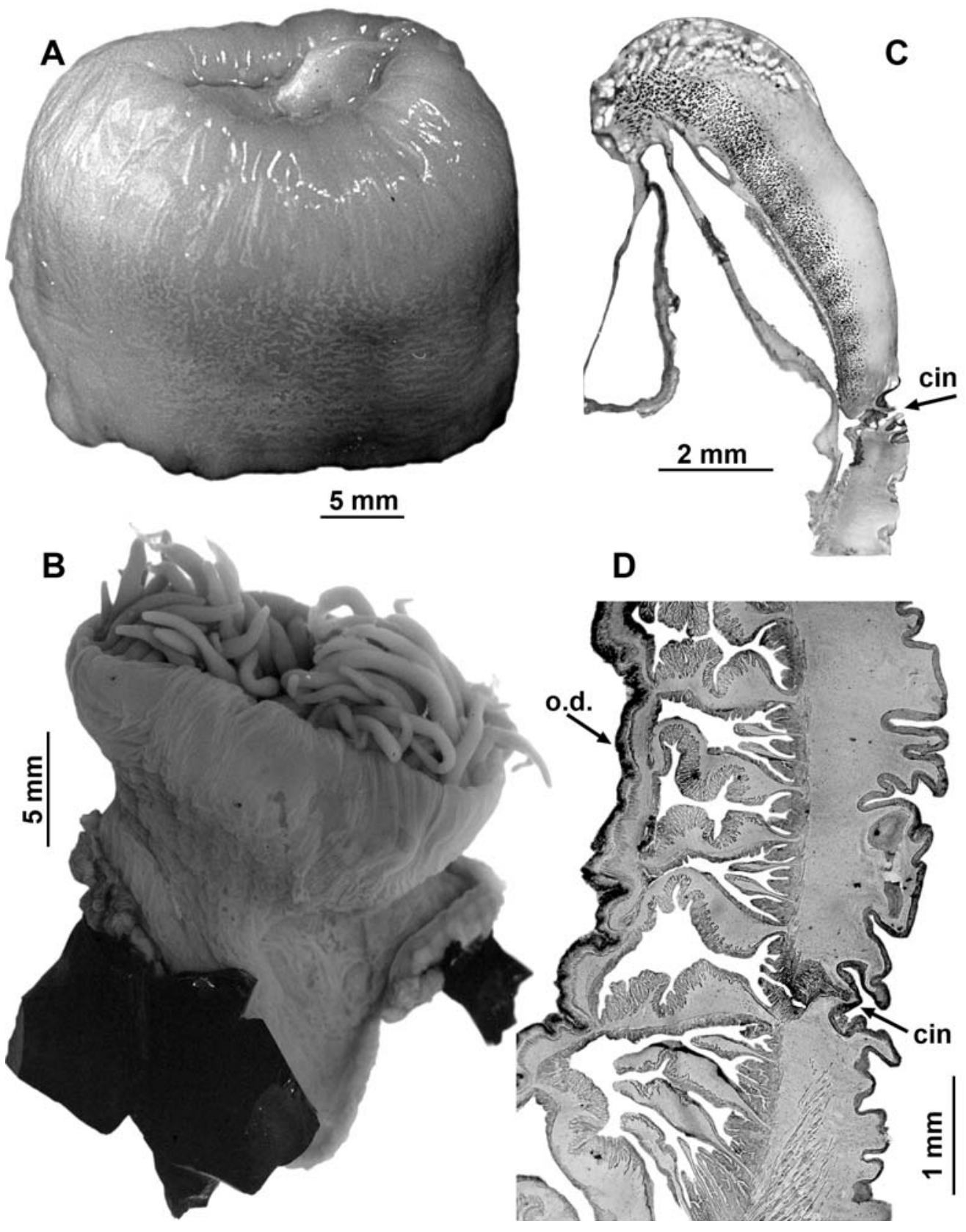

Fig. 10. Cyananthea hydrothermala Doumenc et Van-Praët, 1988.

A, B - external appearance; $\mathrm{C}$ - section of the marginal sphincter; D - cross section at upper portion of column on the level of the ring of cinclides; cin - cinclis; o.d. — oral disc. (A, C - specimen IORAS IV-9-Act-07-013; B, D specimen IORAS IV-9-Act-07-014).

Fig. 10. Cyananthea hydrothermala Doumenc et Van-Praët, 1988.

A, В - внешний вид; C - срез маргинального сфинктера; D - поперечный срез колумна на уровне круга цинклид; cin — цинклида; o.d. — оральный диск. (A, C — экземпляр IORAS IV-9-Act-07-013; B, D — экземпляр IORAS IV-9-Act-07-014). 
cantly more numerous proximally, while gracile spirocysts become more numerous and larger distally.

Remarks. The original description of C. hydrothermala is incomplete and based on a single strongly damaged specimen but contains enough details allowing identification of the present specimens with this species. According to Doumenc and VanPraët (1988) C. hydrothermala is abundant on the EPR $13^{\circ} \mathrm{N}$, and is the only species occurring in the warm $\left(12-20^{\circ} \mathrm{C}\right)$ vent zone on the walls of hydrothermal buildings. The present specimens were collected on the hydrothermal sites of the same region (EPR $9^{\circ} \mathrm{N}$ and $21^{\circ} \mathrm{N}$ ) and from the same environment (vertical walls of the hydrothermal buildings). The presence of two times more mesenteries distally than proximally, a feature originally reported by Doumenc and Van-Praët (1988) is confirmed in the present study. Diagnosis of this species published by Desbruyères and Segonzac (1997: 28) does not correspond to the original diagnosis given by Doumenc and Van-Praët (1988) in some details. According to the former authors "tentacles [are] attached to the oral disc centre" (up to oral disc centre in original diagnosis) and the marginal sphincter is on ectodermic face (endodermic in original diagnosis).

Familial placement of Cyananthea. Doumenc and Van-Praët (1988) failed to detect acontia in this species in situ, on photographs, and in the examined specimen and tentatively assigned it to Actinostolidae, although mentioned that the species has certain (unspecified) characters of Acontiaria. We also failed to detect any traces of acontia or masses of discharged nematocysts usually found in deep-water species in which acontia often disintegrate during the process of sampling. However, the presence of a ring of cinclides suggests an affinity to one of the group of acontiarian anemones or deriving from an acontiarian species by reduction of acontia. The cnidom of $C$. hydrothermala with robust "hormathiid" spirocysts and absence of p-mastigophores A is characteristic for "early Mesomyaria" (in particular for closely related Hormathiidae, Actinoscyphiidae and Kadosactiidae) and inconsistent with its position in the Actinostolidae ("late Mesomyaria"). $C y$ ananthea, with the probable absence of acontia, is assigned tentatively to the Actinoscyphiidae in the present paper, although in certain features (especially a ring of cinclides) it strongly resembles Kadosactis.

The family Actinoscyphiidae, originally created by Stephenson (1920), was reinstated and redefined by Riemann-Zürneck (1978) who removed the two closely related deep-water generaActinoscyphia and Epiparactis from the Actinostolidae to the Actinoscyphiidae. The main reason for separating the Actinoscyphiidae from the Actinostolidae was abovementioned difference in cnidom: absence of thin- walled p-mastigophores A and presence of thickwalled p-mastigophores B in all tissues and, additionally, robust "hormathiid" spirocysts in the tentacles (Riemann-Zürneck, 1978). By removing Actinoscyphia from the key of actinostolid genera Fautin and Hessler (1989) accept the separation between the Actinostolidae and the Actinoscyphiidae and thus apparently agree with the argumentation of Riemann-Zürneck (1978). However,Epiparactis was included in this key without mentioning that it was removed from the Actinostolidae by Riemann-Zürneck (1978), and Marianactis (described in the same paper) is placed in the Actinostolidae although it has robust spirocysts, apparently has no p-mastigophores $\mathrm{A}$ and, thus (if primary importance of cnidom features claimed by Riemann-Zürneck (1978) is accepted), cannot be placed to the Actinostolidae. Although the cnidom of many species assigned to the Actinostolidae is insufficiently known, in the present paper we are inclined to agree with Riemann-Zürneck (1978) that the presence of p-mastigophores A (often associated with the absence of robust spirocysts in tentacles) is a significant feature of the Actinostolidae: Riemann-Zürneck (1978) reported the presence of these cnidae in Actinostola, Paractinostola and Stomphia, and, in addition, we found them inSicyonis, Antholoba, Ophiodiscus andParanthus.

Relation of Cyananthea and other genera. Several monotypic genera described recently from hydrothermal vents are closely related to Cyananthea. Pacmanactis hashimotoiLópez-González et al., 2005 is especially similar in its cnidom and internal morphology with 12 pairs of perfect mesenteries, and differs only in an equal number of mesenteries distally and proximally (while Cyananthea has an additional fifth cycle of mesenteries distally). "Tuberclelike" structures in directive endocoels in P. hashimotoi are similar to cinclides found in C. hydrothermala. Similar cinclides, often on a short tubercles or papillae, are characteristic for certain genera possessing acontia, but not for the Actinostolidae. In particular, several species of Amhianthus (Hormathiidae) have one cinclis in each directive endocoel similar to tubercles on the photo reproduced by López-González et al. (2005, Figs 3D-F). Cinclides were not reported for another monotypic vent genus Marianactis. Nevertheless, the cnidom of Marianactis bythios Fautin et Hessler, 1989 is almost identical with those of $C$. hydrothermala. Actually there are only a few minor differences, e.g. rare basitrichs in filaments and pharynx observed in the present specimens not found in $M$. bythios, tentacle basitrichs in $M$. bythios are larger and heterotrichs not reported. The most striking similarity is extremely numerous mastigophores on the aboral basal portion of the outer tentacles, sometimes forming a solid 
layer in both species. Identified as p-mastigophores in Cyananthea and as amastigophores in Marianactis these cnidae are very similar and both belong to "p-rhabdoids B" sensu Schmidt (1972). The same cnidae are concentrated on the aboral sides of the outer tentacles in Pacmanactis supporting the hypothesis concerning a close relationship of three species. At our opinion Pacmanactis and Marianactis should be removed from the Actinostolidae and placed in the same family as Cyananthea.

\section{Conclusion}

Sea anemones known from hydrothermal vents include obligate hydrothermal taxons (known only from hydrothermal sites) and nonobligate taxons.

In the Atlantic only one obligate hydrothermal species has been documented: Maractis rimicarivo$r a$ Fautin et Barber, 1999. This species is known from the hydrothermal vents of the Mid-Atlantic Ridge (MAR) where it is very abundant in some localities. It has been initially described from the TAG (Trans-Atlantic Geotraverse), and subsequently reported from the Snake Pit (Fautin, Barber, 1999; López-González et al., 2003). It is also present on the MAR $9^{\circ} \mathrm{N}$, Logatchev $\left(14^{\circ} 45.15^{\prime} \mathrm{N}\right)$ and Broken Spur (our unpublished data). Parasicyonis ingolfi Carlgren, 1942 is listed in a "List of sampled and/or observed species" of the Snake Pit hydrothermal site and a reproduced figure shows numerous specimens on the periphery of a hydrothermal building ( $\mathrm{Seg}$ onzac, 1992, Fig. 2). This species has been reported to be "very frequent at the periphery of active edifices" on Snake Pit (Desbruyères, Segonzac, 1997: 30). However, all subsequent authors, who had a chance to examine actual specimens, reported only M. rimicarivora on mid-Atlantic hydrothermal sites (including Snake Pit), where it is very common (Fautin, Barber, 1999; López-González et al., 2003; our unpublished data). There is no doubt, that a record of $P$. ingolfi on Snake Pit is based on a wrong identification of $M$. rimicarivora and this species should be excluded from the list of taxons known from hydrothermal vents.

In the Pacific obligate hydrothermal taxa include the following species: Cyananthea hydrothermala recorded on the walls of black smokers (warm vent zone) of several East Pacific hydrothermal sites $\left(\right.$ EPR $9^{\circ} \mathrm{N}, 13^{\circ} \mathrm{N}$ and $\left.21^{\circ} \mathrm{N}\right)$. Marianactis bythios described from the vicinity of the hydrothermal vents in Mariana back-arc basin, Western Pacific, where it forms crowded settlements of many specimens. Paranthosactis denhartogi López-González et al., 2003 was recorded in Gyaumas Basin. The species was probably collected in a warm vent zone $\left(3^{\circ}-25^{\circ} \mathrm{C}\right)$ since underwater photographs show it with the vestimentiferasRiftia pachyptila.Pacmanac- tis hashimotoi was recorded in Manus Basin vents, south-western Pacific.

Nonobligate species from Pacific hydrothermal vents include Phelliactis pabista and P. callicyclus reported from the Guaymas Basin (present study). Phelliactis hydrothermala sp.n., is reported only from vents (EPR $21^{\circ}$ ), although according to the records made by collectors, it may be a nonobligate species.

Doumenc and Van-Praët (1988) reported several nonobligate species from EPR $13^{\circ}$, which were subsequently included into several lists of hydrothermal fauna (e.g. Desbruyères, Segonzac, 1997). The identification of the specimens, however, appears to be too dubious, or, sometimes wrong. In particular, a species reported by Doumenc and VanPraët (1988) as Actinostola sp. (but the figure is captioned "Actinostola callosa") does not resemble Actinostola in any way. It has distinct longitudinal rows of crowded columnar tubercles, a feature not characteristic for Actinostola. Actinostola callosa reported by Desbruyères and Segonzac (1997) from EPR $13^{\circ}$ certainly is a Phelliactis species. The provided photograph of the living specimen (Desbruyères, Segonzac, 1997: 27) shows a species with longitudinal rows of tubercles on the column, rather long tentacles arranged in several cycles at the periphery of a wide oral disc, and distinct radial ridges running from the mouth to the bases of some tentacles. The latter feature is especially characteristic for Phelliactis. We agree with Arellano and Fautin (2001) who suggested that a specimen identified under the question as "Corallimorpharia" by Doumenc and Van-Praët (1988, Fig. 1) might be a species belonging to the Exocoelactidae.

\section{Acknowledgements}

The authors are grateful to Dr. A.N. Mironov and Dr. S.V. Galkin (Institute of Oceanology, Moscow) for the material provided.

\section{References}

Arellano S.M., Fautin D.G. 2001. Redescription and range extension of the sea anemone Exocoelactis actinostoloides (Wassilieff, 1908), with revision of genus Exocoelactis (Cnidaria: Anthozoa: Actiniaria) // Zoosystema. Vol.23. No.4. P.645-657.

Carlgren O. 1934. Ceriantharia, Zoantharia and Actiniaria // Report on Scientific Research "Michael Sars" North Atlantic Deep-Sea Expedition 1910. Vol.5. P. 1-52.

Carlgren O. 1942. Actiniaria. P.2 // The Danish IngolfExpedition. Vol.5. No.12. P.1-92.

Carlgren O. 1949. A survey of the Ptychodactiaria, Corallimoropharia and Actiniaria // Kungliga Svenska Vetenskapsakademiens Handlingar. Vol.1. No.1. P.1-121. 
Carlgren O. 1956. Actiniaria from depths exceeding 6000 meters // Scientific results of the Danish deep-sea expedition round the World 1950-52. Galathea report. Vol.2. P.9-16.

Daly M., Ardelean A., Cha H., Campbell A.C., Fautin D.G. 2004. A new species, Adamsia obvolva (Cnidaria: Anthozoa: Actiniaria), from the Gulf of Mexico, and a discussion of the taxonomy of carcinoecium-forming sea anemones // Bulletin of Marine Science Vol.74 No.2. P. 385-399.

Desbruyères D., Segonzac M. 1997. Handbook of deep-sea hydrothermal vent fauna / Desbruyères D., Segonzac M. (eds.). Edition IFREMER, Brest, France. 279p.

Doumenc D., Van-Praët M. 1988. Actinies abyssaled d'un site hydrothermal du Pacifique oriental // Oceanologica Acta. Special Vol.8. P.61-68.

Dunn D.F. 1982. Paraphelliactis pabista, a new species of hormathiid sea anemone from abyssal northeastern Pacific waters (Coelenterata: Actiniaria) // Syesis. Vol.15. P.51-56.

England K.W. 1991. Nematocysts of sea anemones (Actiniaria, Ceriantharia and Corallimorpharia: Cnidaria): nomenclature // Hydrobiologia. Vol.216/217. P.691-697.

Fautin D.G., Barber, B.R. 1999. Maractis rimicavrivo$\mathrm{ra}$, a new genus and species of sea anemone (Cnidaria: Anthozoa: Actiniaria: Actinostolidae) from an Atlantic hydrothermal vent // Proceedings of the biological society of Washington. Vol.112. No.3. P.624-631.

Fautin D.G., Hessler R.R. 1989. Marianactis bythios, a new genus and species of actinostolid sea anemone (Coelenterata: Actiniaria) from the Mariana vents // Proceedings of the biological society of Washington. Vol.102. No.4. P.815-825.

Galkin S.V. 2002. [Spatial-ecological structure and biogeography of hydrothermal vent communities] // Gebruk A. (ed.). Biology of hydrothermal systems. Moscow: KMK Sci. Press Ltd. P.363-409 [In Russian].

Hertwig R. 1882. Die actinien der Challengerexpedition. Jena: Gustav Fisher. 136p.

López-González P.J., Rodriguez E., Gili J.-M, Segonzac M. 2003. New records on sea anemones (Anthozoa: Actiniaria) from hydrothermal vents and cold seeps // Zoologische Verhandelingen Leiden. Vol.345. P.215-243

López-González P.J., Rodriguez E., Segonzac M. 2005. A new species of sea anemone (Cnidaria: Anthozoa: Actiniaria) from Manus Basin hydrothermal vents, south-western Pacific // Marine Biology Research. Vol.1. P.326-337.

Molodtsova T.N., Sanamyan N.P., Keller N.B. Anthozoa from the north Mid-Atlantic Ridge and Charlie-Gibbs Fracture Zone // Marine Biology Research (in preparation).

Moskalev L.I. 2002. [Discovery and exploration of hydrothermal vents and cold methane and sulphide seeps in the ocean]// Gebruk A. (ed.). Biology of hydrothermal systems. Moscow: KMK Sci. Press Ltd. P.25-58 [In Russian].

Riemann- Zürneck K. 1991. The abyssal sea anemone Kadosactis sulcata Carlgren 1934 (Cnidaria, Actiniaria: Kadosactidae nov. fam.) // Senckenbergiana marit. Vol.21. S.191-204.

Riemann- Zürneck, K., 1997. The deep-sea anemones Bathyphellia margaritacea and Daontesia porcupina sp.n. with comments on the family Bathyphellidae // Journal of the Marine Biological Association of the United Kingdom. Vol.77. P.361-374.

Riemann-Zürneck K. 1973. Actiniaria des Sudwestatlantik. 1. Hormathiidae//Helgolander wiss. Meeresunters. Vol.25. P.273-325

Riemann-Zürneck K. 1978. Tiefsee-Actinien der Familie Actinoscyphiidae aus dem Nordatlantik (Actiniaria, Mesomyaria) // Zoologica Scripta. Vol.7. P.145-153.

Riemann-Zürneck K. 1986. On some abyssal sea anemones of the North Atlantic (Actiniaria: Hormathiidae) // Mitteilungen aus dem Hamburgischen Zoologischen Museum und Institut. Bd.83. S.7-29.

Rodriguez E., Lopez-Gonzalez P.J. 2001. A new species of Hormathia (Actiniaria, Hormathiidae) from the Eastern Weddel Sea, Antactica // Helgolander Marine Research. Vol.55. P.116-123.

Schmidt H. 1972. Prodromus zu einer Monographie der mediterranean Aktinien // Zoologica. Bd.121. S.1-146.

Schmidt H. 1974. On evolution in the Anthozoa // Proceeding of the Second International Coral Reef Symposium. Bd.1. S.533-560.

Segonzac M. 1992. Les peuplements associés a l'hydrothermalisme océanique du Snake Pit (dorsale médio-atlantique; $23^{\circ} \mathrm{N}, 3480 \mathrm{~m}$ ): composition et microdistribution de la mégafaune // Comptes Rendus de l'Academie des Sciences, Paris. Vol.314. No.3. P.593-600.

Stephenson T.A. 1920. On the classification of Actiniaria. Part 1. Forms with acontia and forms with a mesogloeal sphincter // Quarterly Journal of Microscopical Science. Vol.64. No.4. P.425-574. 